\title{
Contributions of nitrated aromatic compounds to the light absorption of water-soluble and particulate brown carbon in different atmospheric environments in Germany and China
}

\author{
Monique Teich ${ }^{1}$, Dominik van Pinxteren ${ }^{1}$, Michael Wang ${ }^{2}$, Simonas Kecorius $^{1}$, Zhibin Wang ${ }^{1, a}$, Thomas Müller ${ }^{1}$, \\ Griša Močnik $^{3,4}$, and Hartmut Herrmann ${ }^{1}$ \\ ${ }^{1}$ Leibniz Institute for Tropospheric Research, TROPOS, 04315 Leipzig, Germany \\ ${ }^{2}$ McMaster University, Hamilton, ON L8S 4L8, Canada \\ ${ }^{3}$ Aerosol d.o.o., 1000 Ljubljana, Slovenia \\ ${ }^{4}$ Condensed Physics Department, Jožef Stefan Institute, Ljubljana, Slovenia \\ anow at: Multiphase Chemistry Department, Max Planck Institute for Chemistry, 55128 Mainz, Germany
}

Correspondence to: Hartmut Herrmann (herrmann@ tropos.de)

Received: 19 July 2016 - Published in Atmos. Chem. Phys. Discuss.: 25 July 2016

Revised: 24 November 2016 - Accepted: 28 December 2016 - Published: 2 February 2017

\begin{abstract}
The relative contributions of eight nitrated aromatic compounds (NACs: nitrophenols and nitrated salicylic acids) to the light absorption of aqueous particle extracts and particulate brown carbon were determined from aerosol particle samples collected in Germany and China.

High-volume filter samples were collected during six campaigns, performed at five locations in two seasons: (I) two campaigns with strong influence of biomass-burning (BB) aerosol at the TROPOS institute (winter, 2014, urban background, Leipzig, Germany) and the Melpitz research site (winter, 2014, rural background); (II) two campaigns with strong influence from biogenic emissions at Melpitz (summer, 2014) and the forest site Waldstein (summer, 2014, Fichtelgebirge, Germany); and (III) two CAREBeijing-NCP campaigns at Xianghe (summer, 2013, anthropogenic polluted background) and Wangdu (summer, 2014, anthropogenic polluted background with a distinct BB episode), both in the North China Plain.

The filter samples were analyzed for NAC concentrations and the light absorption of aqueous filter extracts was determined. Light absorption properties of particulate brown carbon were derived from a seven-wavelength aethalometer during the campaigns at TROPOS (winter) and Waldstein (summer). The light absorption of the aqueous filter extracts was found to be $\mathrm{pH}$ dependent, with larger values at higher $\mathrm{pH}$. In general, the aqueous light absorption coefficient $\left(\mathrm{Abs}_{370}\right)$
\end{abstract}

ranged from 0.21 to $21.8 \mathrm{Mm}^{-1}$ under acidic conditions and 0.63 to $27.2 \mathrm{Mm}^{-1}$ under alkaline conditions, over all campaigns. The observed mass absorption efficiency $\left(\mathrm{MAE}_{370}\right)$ was in a range of $0.10-1.79 \mathrm{~m}^{2} \mathrm{~g}^{-1}$ and $0.24-2.57 \mathrm{~m}^{2} \mathrm{~g}^{-1}$ for acidic and alkaline conditions, respectively. For MAE 370 and $\mathrm{Abs}_{370}$, the observed values were higher in winter than in summer, in agreement with other studies. The lowest MAE was observed for the Waldstein (summer) campaign (average of $0.17 \pm 0.03 \mathrm{~m}^{2} \mathrm{~g}^{-1}$ ), indicating that freshly emitted biogenic aerosols are only weakly absorbing. In contrast, a strong relationship was found between the light absorption properties and the concentrations of levoglucosan, corroborating findings from other studies.

Regarding the particulate light absorption at $370 \mathrm{~nm}$, a mean particulate light absorption coefficient $b_{\mathrm{abs}, 370}$ of $54 \mathrm{Mm}^{-1}$ and $6.0 \mathrm{Mm}^{-1}$ was determined for the TROPOS (winter) and Waldstein (summer) campaigns, respectively, with average contributions of particulate brown carbon to $b_{\mathrm{abs}, 370}$ of $46 \%$ at TROPOS (winter) and $15 \%$ at Waldstein (summer). Thus, the aethalometer measurements support the findings from aqueous filter extracts of only weakly absorbing biogenic aerosols in comparison to the more polluted and $\mathrm{BB}$ influenced aerosol at TROPOS (winter).

The mean contribution of NACs to the aqueous extract light absorption over all campaigns ranged from 0.10 to $1.25 \%$ under acidic conditions and 0.13 to $3.71 \%$ under 
alkaline conditions. The high variability among the measurement sites showed that the emission strengths of lightabsorbing compounds and the composition of brown carbon were very different for each site. The mean contribution of NACs to the particulate brown carbon light absorption was $0.10 \pm 0.06 \%$ (acidic conditions) and $0.13 \pm 0.09 \%$ (alkaline conditions) during the Waldstein (summer) campaign and $0.25 \pm 0.21 \%$ (acidic conditions) and $1.13 \pm 1.03 \%$ (alkaline conditions) during the TROPOS (winter) campaign.

The average contribution of NACs to the aqueous extract light absorption over all campaigns was found to be 5 times higher than their mass contribution to water-soluble organic carbon indicating that even small amounts of light-absorbing compounds can have a disproportionately high impact on the light absorption properties of particles.

\section{Introduction}

Organic components of atmospheric aerosols are usually treated as solely light scattering in global climate models over the near-ultraviolet and visible range (UV/Vis) of the solar spectrum and therefore only make a negative contribution to radiative forcing (Feng et al., 2013). However, the existence of light-absorbing organic carbon (OC) has become more and more evident in the past decade and can be a regionally important phenomenon (see reviews of Andreae and Gelencser, 2006, and, more recently, Laskin et al., 2015, and references therein and Ulevicius et al., 2010). In contrast to black carbon (BC), which absorbs light efficiently over the whole visible and UV region, light absorbtion by OC exhibits a distinct wavelength dependence. The light absorption sharply increases with decreasing wavelength, making it an efficient absorber in the UV/Vis range. Due to its characteristic yellowish to brownish color, light-absorbing $\mathrm{OC}$ is also often addressed as brown carbon (BrC).

The light absorption by $\mathrm{BrC}$ over the whole solar spectrum are found to be relatively weak compared to BC (J. Liu et al., 2013). Nevertheless, at near-UV/Vis wavelengths (300$500 \mathrm{~nm}) \mathrm{BrC}$ has a non-negligible effect on radiative forcing and the regional and global climate (e.g., Bahadur et al., 2012; Feng et al., 2013; Jo et al., 2016; Park et al., 2010). For instance, modeling studies showed that the radiative forcing of $\mathrm{BrC}$ relative to $\mathrm{BC}$ is up to $25 \%$ (Feng et al., 2013). Furthermore, BrC light absorption in the UV range of the spectrum may alter the concentrations of atmospheric oxidants due to reduced photolysis rates (Jacobson, 1999).

The light absorption of ambient particles is generally quantified by the determination of the particulate light absorption coefficient $b_{\mathrm{abs}}$, (in $\mathrm{Mm}^{-1}$ ), which can be normalized by the sample mass to give the mass absorption efficiency (MAE; in $\mathrm{m}^{2} \mathrm{~g}^{-1}$ ). MAE can then further be used to estimate the radiative forcing of particulate $\mathrm{BrC}$, which makes it an important parameter for modeling studies. These models start with modeled emitted mass, which is converted into concentrations using a dispersion model. The absorption of aerosols in the atmosphere is then determined using the appropriate MAE (Feng et al., 2013). The wavelength dependence of light absorption of a particle sample is described by the absorption Ångström exponent (AAE) based on the power-law dependence of $b_{\text {abs }}$ :

$\frac{b_{\mathrm{abs}, \lambda_{1}}}{b_{\mathrm{abs}, \lambda_{2}}}=\left(\frac{\lambda_{1}}{\lambda_{2}}\right)^{-\mathrm{AAE}}$.

$\mathrm{BC}$ has a weak wavelength dependence and often an AAE of 1.0 is assumed, which is the Mie theoretical value, though measured values range between 0.8 and 1.1 (Gyawali et al., 2009). Values greater than 1.1 indicate a stronger wavelength dependence and give evidence for the presence of absorbers at lower wavelengths, such as $\mathrm{BrC}$ and mineral dust (Wang et al., 2013).

Several methods exist to quantify the light absorption properties of BrC. Filter-based and multi-wavelength measurement techniques are commonly used to assess the contribution of $\mathrm{BrC}$ to the total aerosol light absorption (Moosmüller et al., 2009). One of these instruments is the seven-wavelength aethalometer, which operates from 370 to $940 \mathrm{~nm}$. Due to the main light absorption of $\mathrm{BrC}$ at short wavelengths, the $370 \mathrm{~nm}$ channel is of particular interest. To estimate the contributions of $\mathrm{BrC}$ and $\mathrm{BC}$ to aerosol light absorption, a simple approach based on wavelength pairs and assumed AAEs to distinguish between the light absorption of $\mathrm{BC}$ and $\mathrm{BrC}$ has often been used (Lack and Langridge, 2013; Sandradewi et al., 2008).

Another method is to extract aerosol particles into solvents, mostly water or methanol (e.g., Bosch et al., 2014; Chen and Bond, 2010; Cheng et al., 2011; J. Liu et al., 2013). The advantage of this approach is that BC is insoluble in these solvents and therefore removed by filtration. The extracts are then further analyzed by UV/Vis spectrophotometry. Commonly, light absorption at $365 \mathrm{~nm}$ is used to characterize water-soluble $\mathrm{BrC}$ (e.g., Bosch et al., 2014; Cheng et al., 2011; Hecobian et al., 2010). This wavelength is in a range where the light absorption of inorganics does not interfere, whereas the light absorption of organics shows a sufficiently high intensity (Hecobian et al., 2010). Observed MAE values (related to the water-soluble $\mathrm{OC}$, WSOC) for water-soluble $\mathrm{BrC}$ typically range between 0.41 and $1.80 \mathrm{~m}^{2} \mathrm{~g}^{-1}$ (Cheng et al., 2016; Hecobian et al., 2010), where higher values are usually found in winter.

Until now, field measurements of the light absorption properties of water-soluble $\mathrm{BrC}$ have been performed mostly in the US and Asia, and measurements in Europe are scarce. Duarte et al. (2005) investigated the optical properties of WSOC from aerosol samples collected at a rural site in Portugal. They found a seasonal variation with a higher absorptivity in autumn than in summer. Some studies have reported the optical properties of humic-like substances (HULIS), which 
are a part of WSOC (e.g., Baduel et al., 2010; Utry et al., 2013).

Sources of $\mathrm{BrC}$ are very diverse. Known primary sources are biomass burning (BB; Kirchstetter and Thatcher, 2012; Lack et al., 2013; Mohr et al., 2013) and fossil fuel and residential coal combustion (Bond, 2001; Olson et al., 2015). Moreover, $\mathrm{BrC}$ can be produced by secondary reactions of anthropogenic (Lin et al., 2015a; Nakayama et al., 2010) or biogenic precursors (Flores et al., 2014; Kampf et al., 2012; Lin et al., 2014).

The molecular composition of $\mathrm{BrC}$ still remains largely unknown due to its complex nature. Several attempts have been made to characterize $\mathrm{BrC}$ at a molecular level (Lin et al., 2015a, b). Among the identified compound groups are large macromolecules, like HULIS (Hoffer et al., 2006), aldol condensation products (Noziere and Esteve, 2005, 2007) and nitrogen-containing compounds formed by the reaction of atmospheric aldehydes with ammonia or amines, e.g., imidazoles (Galloway et al., 2009; Lin et al., 2015b; Yu et al., 2011). Nitrated aromatic compounds (NACs), which are the focus of the present study, comprise another group of major contributors to BrC (Jacobson, 1999; Mohr et al., 2013). Nitrophenols (NPs) can be either emitted directly into the atmosphere, e.g., by traffic exhaust (Nojima et al., 1983; Tremp et al., 1993) and wood burning (Hoffmann et al., 2007), or secondarily formed by the nitration of precursor compounds like phenol either in the gas phase or liquid phase (Bolzacchini et al., 2001; Vione et al., 2002). NPs have been quantified at many different locations, especially in Europe (Cecinato et al., 2005; Iinuma et al., 2010; Kahnt et al., 2013; Zhang et al., 2010), but there is surprisingly little information on NP concentrations in Asia (Chow et al., 2015). Nitrated salicylic acids (NSAs) have also been recently detected in atmospheric aerosol particles (Kitanovski et al., 2012; van Pinxteren and Herrmann, 2007). A strong correlation with nitrate was found by Kitanovski et al. (2012) in samples from Ljubljana, Slovenia, suggesting secondary formation from precursor compounds such as salicylic acid, which has been found in biomass-burning aerosols as a lignin degradation product (Iinuma et al., 2007).

Studying $\mathrm{BrC}$ at a molecular level is considered important, since even trace levels of a compound could have a significant impact on the light absorption properties of particles (Kampf et al., 2012). However, little is known about the contributions of specific light-absorbing compounds to the light absorption of either ambient aerosols or aqueous extracts from ambient particles. Mohr et al. (2013) estimated the relative contribution of NACs to particulate BrC light absorption to be about $4 \%$ at $370 \mathrm{~nm}$ at a measurement site in the United Kingdom with high influence of BB aerosols. Zhang et al. (2013) calculated a contribution of NACs to aqueous extract light absorption of $4 \%$ from the Los Angeles Basin (USA).

The present study aims to expand the understanding of $\mathrm{BrC}$ and water-soluble $\mathrm{BrC}$ by investigating its spatial and temporal variation in different, very diverse environments (urban, rural, biogenic, high BB influence). Furthermore, the contribution of individual light-absorbing organic compounds to the $\mathrm{BrC}$ light absorption is included.

\section{Experimental}

\subsection{Measurement campaigns}

Measurements took place at five sampling sites (three German and two Chinese), in six different atmospheric conditions. An overview over the sites, sampling periods, geographical coordinates and the type of atmospheric environment is given in Table 1. Average temperatures and wind speeds are given as campaign averages.

The Leibniz Institute for Tropospheric Research (TROPOS (winter) campaign, 2014) is located in Leipzig in eastern Germany and can be regarded as a moderately polluted urban background site impacted by a mixture of various sources (van Pinxteren et al., 2016). During the measurement period this site was strongly influenced by BB aerosols, as indicated by high levoglucosan concentrations. The first half of the campaign (24 to 31 January) was characterized by low $12 \mathrm{~h}$ mean temperatures $\leq 0^{\circ} \mathrm{C}$. Afterwards, the temperature gradually increased towards the end of the campaign (up to $10^{\circ} \mathrm{C}$ as $12 \mathrm{~h}$ mean). The periods of lower temperatures often coincided with increased emissions from residential heating. The average wind speed was $2.2 \mathrm{~m} \mathrm{~s}^{-1}$.

The measurement site Waldstein in the Bavarian Fichtel Mountains (Waldstein (summer) campaign, 2014; Plewka et al., 2006) is located about $180 \mathrm{~km}$ southwest of Leipzig in a low mountain range. The site is surrounded by forest, where spruce is the dominant species. Measurements took place on a tower at a height of $21 \mathrm{~m}$ (about $780 \mathrm{~m}$ above sea level). The measurement period was characterized by low wind speeds $\left(<1.3 \mathrm{~m} \mathrm{~s}^{-1}\right)$ and predominantly sunny weather (average temperature of $19^{\circ} \mathrm{C}$ ). Because of the surrounding forest, the influence of freshly emitted biogenic organics is expected to be high.

Measurements at Melpitz, a rural background site, located about $50 \mathrm{~km}$ northeast of Leipzig, were carried out in winter (Melpitz (winter) campaign, 2014) and summer (Melpitz (summer) campaign, 2014). The Melpitz (winter) campaign was characterized by an average temperature of $-3^{\circ} \mathrm{C}$ and an average wind speed of $2.8 \mathrm{~m} \mathrm{~s}^{-1}$. The Melpitz (summer) campaign was characterized by an average temperature of $22^{\circ} \mathrm{C}$ and a mean wind speed of $2.0 \mathrm{~m} \mathrm{~s}^{-1}$. The dates in winter and summer correspond to the measurement periods of the TROPOS (winter) and Waldstein (summer) campaigns, respectively. Due to the proximity of TROPOS and Melpitz, the two sites are influenced by similar regional air masses.

The Chinese measurement sites Xianghe (Xianghe (summer) campaign, 2013) and Wangdu (Wangdu (summer) campaign, 2014) are both located in the Hebei Province in the 
Table 1. Overview over sampling sites, used terminology, sampling period, sampling time given in local time (LT) and according atmospheric conditions during the sampling period.

\begin{tabular}{|c|c|c|c|c|}
\hline Sampling site & Designation & $\begin{array}{l}\text { Geographic } \\
\text { coordinates }\end{array}$ & $\begin{array}{l}\text { Sampling period (sam- } \\
\text { pling duration per filter) }\end{array}$ & Comments \\
\hline \multicolumn{5}{|l|}{ Germany } \\
\hline $\begin{array}{l}\text { Roof of the Leibniz In- } \\
\text { stitute for Tropospheric } \\
\text { Research, Leipzig }\end{array}$ & $\begin{array}{l}\text { TROPOS } \\
\text { (winter) }\end{array}$ & $\begin{array}{l}51.35^{\circ} \mathrm{N} \\
12.43^{\circ} \mathrm{E}\end{array}$ & $\begin{array}{l}24 \text { January to } 8 \text { Febru- } \\
\text { ary } 2014(12 \mathrm{~h} \text {, day, } \\
06: 00-18: 00 \mathrm{LT} \text {, and } \\
\text { night, 18:00-06:00 LT) }\end{array}$ & $\begin{array}{l}\text { Urban background, strong influence of } \\
\text { biomass-burning aerosol during mea- } \\
\text { surement period (van Pinxteren et al., } \\
\text { 2016) }\end{array}$ \\
\hline \multirow[t]{2}{*}{ Melpitz } & $\begin{array}{l}\text { Melpitz } \\
\text { (winter) }\end{array}$ & $\begin{array}{l}51.53^{\circ} \mathrm{N} \\
12.93^{\circ} \mathrm{E}\end{array}$ & $\begin{array}{l}24 \text { January to } 4 \text { Febru- } \\
\text { ary } 2014(24 \mathrm{~h}, 00: 00- \\
24: 00 \mathrm{LT})\end{array}$ & $\begin{array}{l}\text { Rural background (Spindler et al., } \\
\text { 2010) }\end{array}$ \\
\hline & $\begin{array}{l}\text { Melpitz } \\
\text { (summer) }\end{array}$ & & $\begin{array}{l}16 \text { to } 25 \text { July } 2014 \\
(24 \mathrm{~h}, 00: 00-24: 00 \mathrm{LT})\end{array}$ & \\
\hline $\begin{array}{l}\text { Bavarian Fichtel Moun- } \\
\text { tains }\end{array}$ & $\begin{array}{l}\text { Waldstein } \\
\text { (summer) }\end{array}$ & $\begin{array}{l}50.14^{\circ} \mathrm{N} \\
11.87^{\circ} \mathrm{E}\end{array}$ & $\begin{array}{l}16 \text { July to } 25 \text { July } \\
2014 \text { (11 h, day, 07:00- } \\
\text { 18:00 LT, and night, } \\
\text { 19:00-06:00 LT) }\end{array}$ & $\begin{array}{l}\text { BayCEER Waldstein observatory, F- } \\
\text { BEACH campaign, surrounded by for- } \\
\text { est, high local biogenic emissions } \\
\text { (Plewka et al., 2006) }\end{array}$ \\
\hline \multicolumn{5}{|l|}{ China } \\
\hline Xianghe & $\begin{array}{l}\text { Xianghe } \\
\text { (summer) }\end{array}$ & $\begin{array}{l}39.75^{\circ} \mathrm{N} \\
116.96^{\circ} \mathrm{E}\end{array}$ & $\begin{array}{l}9 \text { to } 14 \text { July and } 21 \\
\text { July } 2013 \text { to } 1 \text { August } \\
2013 \text { (12 h, day, 06:00- } \\
\text { 18:00 LT and night, } \\
\text { 18:00-06:00 LT) }\end{array}$ & $\begin{array}{l}\text { CAREBeijing-NCP } 2013 \text { campaign } \\
\text { (Kecorius et al., 2015), rural back- } \\
\text { ground, urban outflow }\end{array}$ \\
\hline Wangdu & $\begin{array}{l}\text { Wangdu } \\
\text { (summer) }\end{array}$ & $\begin{array}{l}38.71^{\circ} \mathrm{N} \\
115.13^{\circ} \mathrm{E}\end{array}$ & $\begin{array}{l}4 \text { to } 24 \text { June } 2014 \\
\text { (12 h, day, 06:00- } \\
\text { 18:00 LT, and night, } \\
\text { 18:00-06:00 LT) }\end{array}$ & $\begin{array}{l}\text { CAREBeijing-NCP } 2014 \text { campaign, } \\
\text { rural background, biomass burning } \\
\text { episode occurred during the measure- } \\
\text { ment period (Kecorius et al., 2016) }\end{array}$ \\
\hline
\end{tabular}

North China Plain (NCP). The campaigns were part of the CAREBeijing-NCP campaigns in 2013 and 2014. Xianghe is situated between the two megacities of Beijing and Tianjin, and Wangdu is located $170 \mathrm{~km}$ southwest of Beijing. The average temperature and wind speed at the Xianghe (summer) campaign were $26^{\circ} \mathrm{C}$ and $0.8 \mathrm{~m} \mathrm{~s}^{-1}$, respectively. For the Wangdu (summer) campaign a mean temperature of $26^{\circ} \mathrm{C}$ and a mean wind speed of $4 \mathrm{~m} \mathrm{~s}^{-1}$ were measured. Both sites can be regarded as regional background stations for the NCP. In comparison to the summer campaigns in Germany, the average $\mathrm{PM}_{10}$ (particulate matter with an aerodynamic diameter $\leq 10 \mu \mathrm{m}$ ) concentrations were about 3 to 7 times higher at the Chinese sites.

\subsection{Sampling, chemical analysis and back trajectories}

$\mathrm{PM}_{10}$ was collected on quartz fiber filters with a Digitel DHA-80 high volume filter sampler (MK 360, Munktell, Falun, Sweden; flow rate: $0.5 \mathrm{~m}^{3} \mathrm{~min}^{-1}$ ). To minimize blank content, the filters were pre-baked for $24 \mathrm{~h}$ at $105^{\circ} \mathrm{C}$. Day and night samples ( $11 \mathrm{~h}$ or $12 \mathrm{~h}$; see Table 1 ) were taken during each campaign except for Melpitz (winter) and Melpitz (summer), where particles were collected for $24 \mathrm{~h}$. After sampling, filters were stored in clean aluminium tins at $-20^{\circ} \mathrm{C}$ in the dark until extraction (extraction was done within a year after sampling). It is assumed that storage at $-20^{\circ} \mathrm{C}$ prevents chemical degradation of the sample. Analysis of WSOC, levoglucosan, NACs and UV/Vis spectrophotometry measurements was carried out using aqueous filter extracts of different portions of filter in ultrapure water. Details on the different methods are given below. The aqueous filter extract was always filtered through a pre-cleaned syringe filter $(0.45 \mu \mathrm{m}$, Acrodisc 13, Pall, Dreieich, Germany).

NACs and UV/Vis spectra were determined from the aqueous extract by extracting $11-28$ pieces of the filter $\left(1.54 \mathrm{~cm}^{2}\right.$ each) into $10 \mathrm{~mL}$ of ultrapure water. NPs were analyzed according to the method described in Teich et al. (2014) based on hollow fiber liquid-phase micro extraction for analyte enrichment and capillary electrophoresis electrospray ionization mass spectrometry (CE-ESI-MS, Agilent ${ }^{3 \mathrm{D}} \mathrm{CE}$ instrument, Bruker Esquire $3000^{+}$ion trap mass spectrometer). Samples from the Waldstein (summer) campaign were not 
analyzed for NPs due to the limited availability of filter material.

NSAs were enriched by evaporating an alkalinized aliquot of the aqueous filter extract $(1.8 \mathrm{~mL}$ plus $200 \mu \mathrm{L} 10 \mathrm{mM}$ $\mathrm{NaOH}$ ) to dryness in a vacuum concentrator (miVac, Genevac Ltd., UK) and redissolving the residue into $40 \mu \mathrm{L}$ ultrapure water. Subsequent analysis was carried out by CEMS as described in van Pinxteren et al. (2012). Standard addition was carried out for quantifying the NSA compounds by co-injecting a standard solution plug at different concentration levels into the CE capillary after the sample plug.

Overall, eight NACs were determined as part of BrC: 3-nitrosalicylic acid (3NSA) and 5-nitrosalicylic acid (5NSA), 4-nitrophenol (4NP), 2-methyl-4-nitrophenol (2M4NP), 3-methyl-4-nitrophenol (3M4NP), 2,6-dimethyl4-nitrophenol (2,6DM4NP), 2,4-dinitrophenol (2,4DNP) and 3,4-dinitrophenol (3,4DNP). The standard compounds were purchased in high purity ( $\geq 98 \%$ ) from either Fluka or Sigma-Aldrich (Munich, Germany). As a typical BB tracer, levoglucosan can help to investigate the influence of $\mathrm{BB}$ aerosols on the observed concentrations (Iinuma et al., 2009; Simoneit, 2002). Levoglucosan was analyzed with a Dionex ICS-3000 system coupled with a pulsed amperometric detector (Thermo Fisher Scientific, Sunnyvale, CA, USA). A portion of sampled filter $\left(9.42 \mathrm{~cm}^{2}\right)$ was extracted in $20 \mathrm{~mL}$ of ultrapure water by shaking with a laboratory orbital shaker for $120 \mathrm{~min}$. Detailed chromatographic conditions and the merits of analysis can be found elsewhere (Iinuma et al., 2009). Levoglucosan data are available for the campaigns Xianghe (summer), Wangdu (summer) and TROPOS (winter). No data are available for the Melpitz (winter), Melpitz (summer) and Waldstein (summer) campaigns due to limited amount of filter material.

OC and elemental carbon (EC) were determined from the filter by a thermal-optical method using the Sunset Laboratory Dual-Optical Carbonaceous Analyzer (Sunset Laboratory Inc., Tigard, OR, USA) following the EUSAAR 2 temperature protocol and applying a charring correction using light transmission (Cavalli et al., 2010).

The aqueous extract for determining WSOC was prepared by extracting $21.5 \mathrm{~cm}^{2}$ of the filter samples from the $\mathrm{Xi}$ anghe (summer), Wangdu (summer), Melpitz (winter) and Melpitz (summer) campaign and $38.5 \mathrm{~cm}^{2}$ for samples from the campaigns Waldstein (summer) and TROPOS (winter) into 25 and $30 \mathrm{~mL}$ of ultrapure water, respectively, followed by $20 \mathrm{~min}$ of ultrasonication. After filtration, the extract was injected into a TOC- $\mathrm{V}_{\mathrm{CPH}}$ analyzer (Shimadzu, Japan) operating in the NPOC (nonpurgeable organic carbon) mode. More details on the method can be found in van Pinxteren et al. (2009).

The air mass origin was estimated by $96 \mathrm{~h}$ back trajectories calculated using the HYSPLIT model (Stein et al., 2015).

\subsection{Instrumentation for aerosol light absorption measurements}

Particulate light absorption was measured by a sevenwavelength aethalometer, model AE33 (Aerosol d.o.o., Slovenia), during the TROPOS (winter) and Waldstein (summer) campaigns. A detailed description of the instrument is given in Drinovec et al. (2015). Briefly, aerosol particles are collected on a filter tape. Light attenuation is measured continuously through this aerosol laden filter (time resolution of $1 \mathrm{~s})$. When a fixed attenuation threshold is reached, the tape advances to a new filter spot. Filter-based measurements feature nonlinear loading effects, caused by the increasing deposition of the sample in the filter loading during the measurement, and filter matrix light scattering effects (Weingartner et al., 2003). The aethalometer AE33 measures the loading effect by using a dual-spot approach, where attenuation measurements are carried out simultaneously on two differently loaded spots. Multiple scattering effects were compensated by normalizing the particulate light absorption coefficient $b_{\text {abs }}$ against data from a multi-angle absorption photometer (MAAP; Petzold and Schonlinner, 2004) which was also located at the measurement sites. The determined normalization factor (for light scattering effects) $C$ was 1.69 for the TROPOS (winter) campaign and 2.06 for the Waldstein (summer) campaign. More details are given in the Supplement Sect. S1.

The relative contribution of $\mathrm{BrC}$ and $\mathrm{BC}$ to $b_{\mathrm{abs}, 370}$ was determined following the method used by Kirchstetter and Thatcher (2012). For the calculations, it was assumed that $\mathrm{BC}$ was the only absorbing species at $940 \mathrm{~nm}$, that $\mathrm{OC}$ and $\mathrm{BC}$ were externally mixed and that the $\mathrm{AAE}$ of $\mathrm{BC}$ was 1.0. These assumptions are consistent with recently published studies (Martinsson et al., 2015; Mohr et al., 2013). Using Eq. (1), $b_{\mathrm{abs}, 370, \mathrm{BC}}$ was determined by extrapolating from $940 \mathrm{~nm}$ to $370 \mathrm{~nm}$, and the contribution of $\mathrm{BrC}$ was then calculated using Eq. (2):

$b_{\mathrm{abs}, \lambda}=b_{\mathrm{abs}, \lambda, \mathrm{BrC}}+b_{\mathrm{abs}, \lambda, \mathrm{BC}}$.

The AAE was fitted over all seven wavelengths and is given as the average of the wavelength dependencies with the measurement time resolution.

\section{$2.4 \mathrm{UV} / \mathrm{Vis}$ spectrophotometry}

Light absorption of aqueous solutions were measured with a Lambda $900 \mathrm{UV} /$ Vis spectrophotometer (Perkin Elmer) using quartz cells (Secomam, France). The aqueous filter extracts were analyzed at $\mathrm{pH} \approx 2$ (acidified with $\mathrm{H}_{2} \mathrm{SO}_{4}$, in the following also indicated with the subscript "A") and at $\mathrm{pH} \approx 10$ (addition of $\mathrm{NaOH}$, in the following also indicated with the subscript "B"). Hence, the target compounds were either in their neutral or deprotonated state to obtain the lower and upper limit for the contribution of NACs to the $\mathrm{BrC}$ light absorption In principle, it could be possible that 
introducing acids or bases into the system induces unforeseen chemical reactions influencing the total light absorption of the aqueous extract. However, to minimize the risk of potential chemical modification the solutions where kept in the dark and analyzed as soon as possible after preparation by UV-Vis spectrophotometry. The influence of the $\mathrm{pH}$ on MAE and the aqueous light absorption coefficient (Abs) is discussed in Sect. 3.1.1. Spectra were recorded from 300 to $800 \mathrm{~nm}$.

The interpretation of the aqueous extract light absorption follows the method described by Hecobian et al. (2010). In general, according to the Beer-Lambert law the absorbance $\left(A_{\lambda}\right)$ of a solution is defined as

$A_{\lambda}=-\log _{10}\left(\frac{I}{I}{ }_{0}\right)=l \cdot c \cdot \varepsilon_{\lambda}=l \sum_{i}\left(c_{i} \cdot \varepsilon_{\lambda, i}\right)$,

where $I_{0}$ and $I$ are the intensity of the incident and transmitted light, respectively, $l$ the absorbing path length, $c$ the concentration of absorbing species in solution and $\varepsilon_{\lambda}$ is the wavelength-dependent molar extinction coefficient. The resulting data were then converted to $\mathrm{Abs}_{\lambda}$ :

$\operatorname{Abs}_{\lambda}\left[\mathrm{Mm}^{-1}\right]=\left(A_{\lambda}-A_{800}\right) \frac{V_{1}}{V_{\mathrm{a}} \cdot l} \cdot \ln (10)$,

where $A_{800}$ is the reference wavelength to account for any baseline drift, $V_{1}$ is the volume of water used for extraction $(10 \mathrm{~mL}), V_{\mathrm{a}}$ is the volume of air passed through the filter and $\ln (10)$ was used to convert the common logarithm to a natural logarithm. The path length $l$ was either 2 or $5 \mathrm{~cm}$.

$\mathrm{Abs}_{\lambda}$ is the light absorption coefficient of the aqueous extract solutions and is not to be mistaken for $b_{\text {abs }}$, the light absorption coefficient of ambient particles. This nomenclature was chosen in accordance with other studies (J. Liu et al., 2013, 2015).

Using the mass concentration of WSOC (in $\mu \mathrm{g} \mathrm{m}^{-3}$ ), MAE was calculated by

$\operatorname{MAE}\left[\mathrm{m}^{2} \mathrm{~g}^{-1}\right]=\frac{\mathrm{Abs}_{\lambda}}{[\mathrm{WSOC}]}$.

The molar extinction coefficient at $370 \mathrm{~nm}, \varepsilon_{370}$, was determined for each target compound by preparing a dilution series of standard compounds in water. Subsequently, a three point curve was recorded twice. According to the BeerLambert law, the slope of the regression in an absorbanceconcentration plot is proportional to $\varepsilon$. The molar extinction coefficients for each compound under acidic and alkaline conditions are presented in Table S2.

In other studies dealing with aqueous extracts, Abs values were given for $365 \mathrm{~nm}$ (e.g., Bosch et al., 2014; Cheng et al., 2011; Hecobian et al., 2010). We chose $370 \mathrm{~nm}$ to characterize the aqueous extract light absorption properties to match the $370 \mathrm{~nm}$ channel of the aethalometer.

\subsection{Calculation of the contribution of nitrated aromatic compounds to light absorption of aqueous extracts and particulate brown carbon}

The contribution of the target compounds to the aqueous extract light absorption was computed by first calculating the absorbance of the single compound using Eq. (3) and then determining the percentage on the total aqueous solution light absorption.

To assess the contribution of the NACs to particulate $\mathrm{BrC}$ light absorption at $370 \mathrm{~nm}$, the molar extinction coefficient of each compound was converted to the liquid-phase molecular absorption cross section $b_{\text {liq }}$ (Jacobson, 1999):

$b_{\text {liq }}\left[\mathrm{cm}^{2}\right.$ molecule $\left.^{-1}\right]=1000 \ln (10) \frac{\varepsilon_{370}}{N_{\mathrm{A}}}$,

where $N_{\mathrm{A}}$ is the Avogadro constant and $\ln (10)$ is used to convert the common logarithm of the molar extinction coefficient (base 10) to the natural logarithm. The $\mathrm{MAE}_{\text {comp }}$ of each compound was then calculated by dividing $b_{\text {liq }}$ by the mass of one molecule. The subscript "comp" denotes the specific compound. If the $\mathrm{MAE}_{\text {comp }}$ and the mass concentration in air of the compound are known, $b_{\text {abs,comp }}$ of the single compound in ambient particles can be calculated by the following equation:

$b_{\mathrm{abs}, \mathrm{comp}}=\mathrm{MAE}_{\mathrm{com}} \cdot[\mathrm{comp}]$,

where [comp] is the mass concentration of the compound in the aerosol.

By knowing $b_{\mathrm{abs}, \text { comp }}$ and $b_{\mathrm{abs}, \mathrm{BrC}}$, the relative contribution of the individual compound on the particulate $\mathrm{BrC}$ light absorption can be calculated.

\section{Results/discussion}

\subsection{Optical properties of water-soluble and particulate brown carbon}

In the following section, the general optical properties of water-soluble and particulate $\mathrm{BrC}$ are presented. Optical properties of water-soluble $\mathrm{BrC}$ (represented by the aqueous extract light absorption) are given as $\mathrm{MAE}_{370}$ and $\mathrm{Abs}_{370}$. Particulate $\mathrm{BrC}$ was characterized by the particulate light absorption coefficient $\left(b_{\mathrm{abs}, 370}\right)$ and the AAE. The results of the optical properties are summarized in Table 2.

\subsubsection{Influence of acidic and alkaline conditions on the mass absorption efficiency and the aqueous light absorption coefficient}

Values for MAE and Abs have usually been directly derived from filtered aqueous filter extract without considering the pH of the solutions (e.g., Bosch et al., 2014; Cheng et al., 2011; Hecobian et al., 2010). However, depending on the nature of the absorbing species, $\mathrm{pH}$ alters the absorptivity. Alif 
Table 2. Optical properties and calculated contribution of NACs to the light absorption of aqueous extracts and particulate BrC. The values are given as minimum-maximum (mean \pm standard deviation). Acidic conditions are indicated by the letter "A" and alkaline conditions are indicated by the letter "B". Highest and lowest mean values for each category are marked in bold.

\begin{tabular}{|c|c|c|c|c|c|c|}
\hline & $\begin{array}{l}\text { Waldstein } \\
\text { (summer) }\end{array}$ & $\begin{array}{l}\text { Melpitz } \\
\text { (summer) }\end{array}$ & $\begin{array}{l}\text { TROPOS } \\
\text { (winter) }\end{array}$ & $\begin{array}{l}\text { Melpitz } \\
\text { (winter) }\end{array}$ & $\begin{array}{l}\text { Xianghe } \\
\text { (summer) }\end{array}$ & $\begin{array}{l}\text { Wangdu } \\
\text { (summer) }\end{array}$ \\
\hline \multicolumn{7}{|l|}{ Optical properties } \\
\hline $\operatorname{Abs}_{370 \mathrm{~A}}\left(\mathrm{Mm}^{-1}\right)$ & $\begin{array}{l}0.21-0.70 \\
(\mathbf{0 . 5 1} \pm 0.11)\end{array}$ & $\begin{array}{l}0.57-1.34 \\
(0.84 \pm 0.24)\end{array}$ & $\begin{array}{l}0.33-8.96 \\
(3.91 \pm 2.49)\end{array}$ & $\begin{array}{l}1.75-10.6 \\
(4.13 \pm 2.51)\end{array}$ & $\begin{array}{l}0.82-4.68 \\
(2.02 \pm 0.81)\end{array}$ & $\begin{array}{l}1.10-21.8 \\
(\mathbf{4 . 6 4} \pm 4.16)\end{array}$ \\
\hline $\operatorname{Abs}_{370 B}\left(\mathrm{Mm}^{-1}\right)$ & $\begin{array}{l}0.63-1.15 \\
(\mathbf{0 . 8 8} \pm 0.13)\end{array}$ & $\begin{array}{l}0.88-1.78 \\
(1.19 \pm 0.30)\end{array}$ & $\begin{array}{l}0.69-14.5 \\
(\mathbf{6 . 8 0} \pm 3.94)\end{array}$ & $\begin{array}{l}3.28-15.2 \\
(6.63 \pm 3.50)\end{array}$ & $\begin{array}{l}1.20-9.07 \\
(3.16 \pm 1.50)\end{array}$ & $\begin{array}{l}1.87-27.2 \\
(6.65 \pm 5.55)\end{array}$ \\
\hline $\operatorname{MAE}_{370 A}\left(m^{2} g^{-1}\right)$ & $\begin{array}{l}0.10-0.25 \\
(\mathbf{0 . 1 7} \pm 0.03)\end{array}$ & $\begin{array}{l}0.19-0.30 \\
(0.22 \pm 0.03)\end{array}$ & $\begin{array}{l}0.41-1.30 \\
(0.84 \pm 0.20)\end{array}$ & $\begin{array}{l}0.52-1.79 \\
(\mathbf{0 . 8 6} \pm 0.33)\end{array}$ & $\begin{array}{l}0.30-0.52 \\
(0.38 \pm 0.06)\end{array}$ & $\begin{array}{l}0.31-1.01 \\
(0.55 \pm 0.15)\end{array}$ \\
\hline $\operatorname{MAE}_{370 B}\left(m^{2} g^{-1}\right)$ & $\begin{array}{l}0.24-0.36 \\
(\mathbf{0 . 2 9} \pm 0.03)\end{array}$ & $\begin{array}{l}0.27-0.43 \\
(0.31 \pm 0.05)\end{array}$ & $\begin{array}{l}0.86-2.21 \\
(\mathbf{1 . 4 5} \pm 0.29)\end{array}$ & $\begin{array}{l}0.84-2.57 \\
(1.37 \pm 0.45)\end{array}$ & $\begin{array}{l}0.34-1.15 \\
(0.59 \pm 0.14)\end{array}$ & $\begin{array}{l}0.49-1.40 \\
(0.81 \pm 0.21)\end{array}$ \\
\hline$b_{\mathrm{abs} 370}\left(\mathrm{Mm}^{-1}\right)$ & $\begin{array}{l}3.72-8.59 \\
(\mathbf{6 . 2 3} \pm 1.33)\end{array}$ & & $\begin{array}{l}4.13-129.4 \\
(\mathbf{5 4 . 2} \pm 34.07)\end{array}$ & & & \\
\hline$b_{\mathrm{abs} 370, \mathrm{BrC}}\left(\mathrm{Mm}^{-1}\right)$ & $\begin{array}{l}0.62-1.69 \\
(\mathbf{0 . 9 4} \pm 0.28)\end{array}$ & & $\begin{array}{l}1.25-54.4 \\
(\mathbf{2 1 . 8} \pm 14.2)\end{array}$ & & & \\
\hline \multicolumn{7}{|c|}{ Contribution to light absorption (\%) } \\
\hline NACs to $\mathrm{Abs}_{370 \mathrm{~A}}$ & $\begin{array}{l}0.02-0.33 \\
(0.15 \pm 0.10)\end{array}$ & $\begin{array}{l}0.06-0.22 \\
(\mathbf{0 . 1 3} \pm 0.05)\end{array}$ & $\begin{array}{l}0.03-4.22 \\
(\mathbf{1 . 2 1} \pm 0.82)\end{array}$ & $\begin{array}{l}0.15-2.03 \\
(0.87 \pm 0.57)\end{array}$ & $\begin{array}{l}0.04-1.32 \\
(0.46 \pm 0.24)\end{array}$ & $\begin{array}{l}0.24-1.83 \\
(0.56 \pm 0.31)\end{array}$ \\
\hline NACs to $\mathrm{Abs}_{370 \mathrm{~B}}$ & $\begin{array}{l}0.02-0.25 \\
(\mathbf{0 . 1 3} \pm 0.03)\end{array}$ & $\begin{array}{l}0.10-0.48 \\
(0.24 \pm 0.12)\end{array}$ & $\begin{array}{l}0.97-9.71 \\
(\mathbf{3 . 3 5} \pm 2.04)\end{array}$ & $\begin{array}{l}0.47-5.00 \\
(2.48 \pm 1.45)\end{array}$ & $\begin{array}{l}0.21-2.85 \\
(0.1 .02 \pm 0.0 .54)\end{array}$ & $\begin{array}{l}0.56-4.44 \\
(1.34 \pm 0.72)\end{array}$ \\
\hline NACs to $b_{\mathrm{abs} 370, \mathrm{BrC}}(\mathrm{A})$ & $\begin{array}{l}0.01-0.22 \\
(\mathbf{0 . 1 0} \pm 0.06)\end{array}$ & & $\begin{array}{l}0.01-1.13 \\
(\mathbf{0 . 2 5} \pm 0.21)\end{array}$ & & & \\
\hline NACs to $b_{\mathrm{abs}, 370, \mathrm{BrC}}(\mathrm{B})$ & $\begin{array}{l}0.02-0.31 \\
(\mathbf{0 . 1 3} \pm 0.09)\end{array}$ & & $\begin{array}{l}0.01-5.42 \\
(\mathbf{1 . 1 3} \pm 1.03)\end{array}$ & & & \\
\hline
\end{tabular}

et al. $(1987,1990,1991)$ showed for NPs that their anionic form is a much stronger absorber than their neutral form. Moreover, the absorption maximum shifts towards longer wavelengths under alkaline conditions. The dissociation in a solution depends on the $\mathrm{pK}_{\mathrm{a}}$ value of the compound and at different $\mathrm{pH}$ levels different mixtures of neutral/ionized compounds exist. Generally, ambient particles are estimated to be more acidic ( $\mathrm{pH}<4$, Scheinhardt et al., 2013), making the findings under acidic conditions more relevant for ambient conditions. However, Hinrichs et al. (2016) reported that NPs adsorbed to a particle surface exhibit a significant red shift similar to the aqueous light absorption spectrum of their deprotonated form. Hence, under certain conditions the deprotonated forms can also be important.

Comparing alkaline and acidic conditions, strong correlations have been found for Abs, MAE and the relative contribution of the individual compounds to Abs over all campaigns $\left(R^{2} \geq 0.93\right.$, see Fig. S3). On average, Abs 370 increased by a factor of 1.4 and MAE by a factor of 1.6 under alkaline conditions compared to the acidic conditions. As indicated by the good correlation, this factor is quite consistent and independent of the measurement site.

The molar extinction coefficient at $370 \mathrm{~nm}$ increases with $\mathrm{pH}$ for the individual compounds (see Table S2). A higher $\mathrm{pH}$ leads to deprotonation of hydroxyl and carboxyl groups, which may lead to a shift of the absorption maximum towards longer wavelengths. The light absorption of the aqueous extracts is a sum of many different light-absorbing species. Therefore, the relative contribution to the aqueous extract light absorption for individual compounds is affected differently. For example, the relative contribution of 3NSA and 2,6DM4NP to $\mathrm{Abs}_{370}$ decreases at $\mathrm{pH} 10$. No difference in the contribution to Abs 370 was observed for 5NSA. The highest increase in the contribution to $\mathrm{Abs}_{370}$ was found for $2,4 \mathrm{DNP}$ with a factor of 6.8. The observed differences in the contribution to $\mathrm{Abs}_{370}$ are related to both the molar extinction coefficient, which alters with the $\mathrm{pH}$, and the composition of the solution. A decrease in the relative contribution to the light absorption at higher $\mathrm{pH}$ is most likely due to greater contributions of other, now overlapping light-absorbing compounds at this specific wavelength.

The increase of $\mathrm{Abs}_{370}$ with higher $\mathrm{pH}$ is relatively modest (a factor of 1.4) compared to the increase of the molar extinction coefficient of individual NACs (an average factor of 4.5). This might indicate that the absorption properties of the majority of light-absorbing compounds are barely affected by the $\mathrm{pH}$. These findings are only valid for the investigated wavelength of $370 \mathrm{~nm}$ and are likely to differ over the whole spectral range. 
(a)

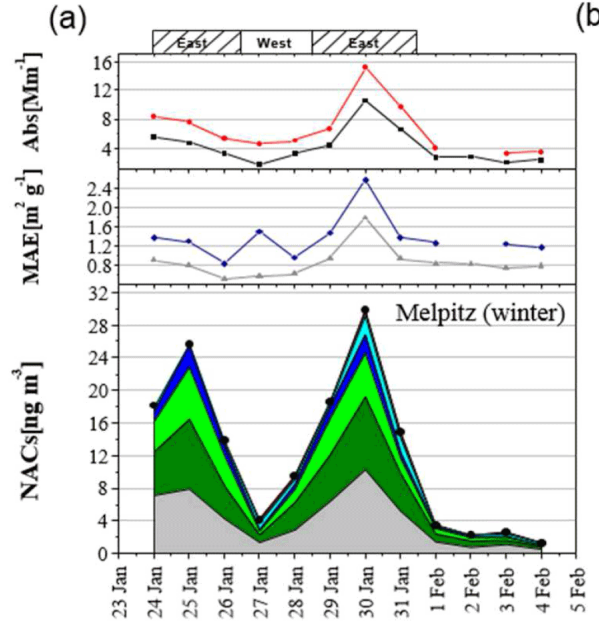

(c)

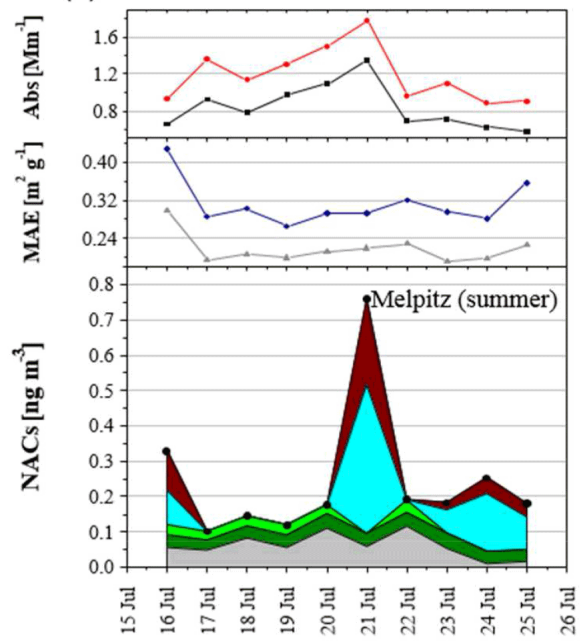

(e)

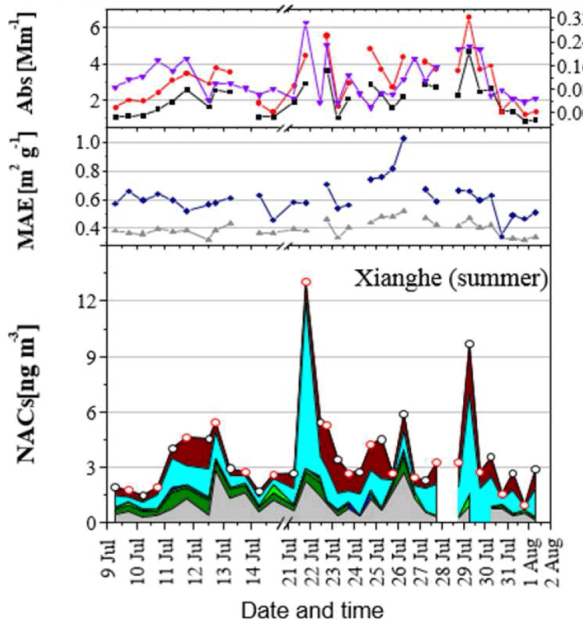

(b)

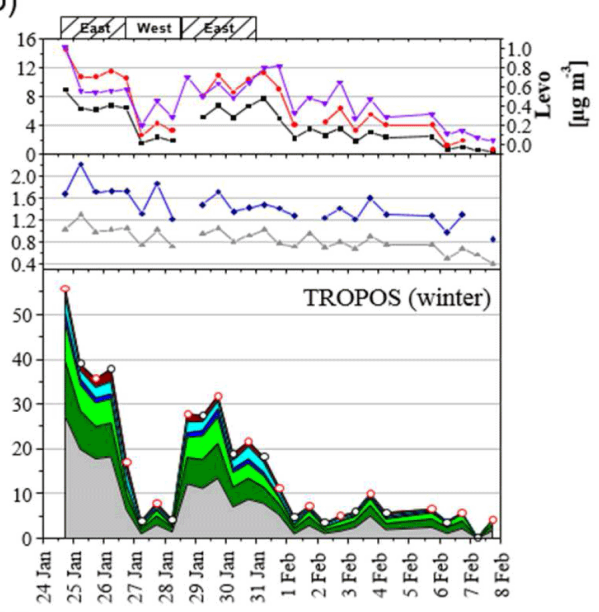

(d)
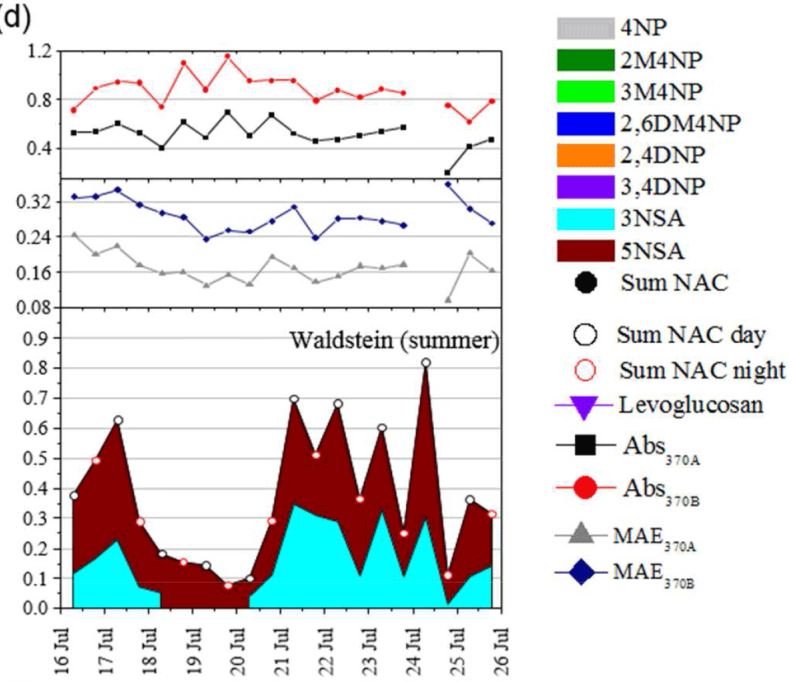

(f)

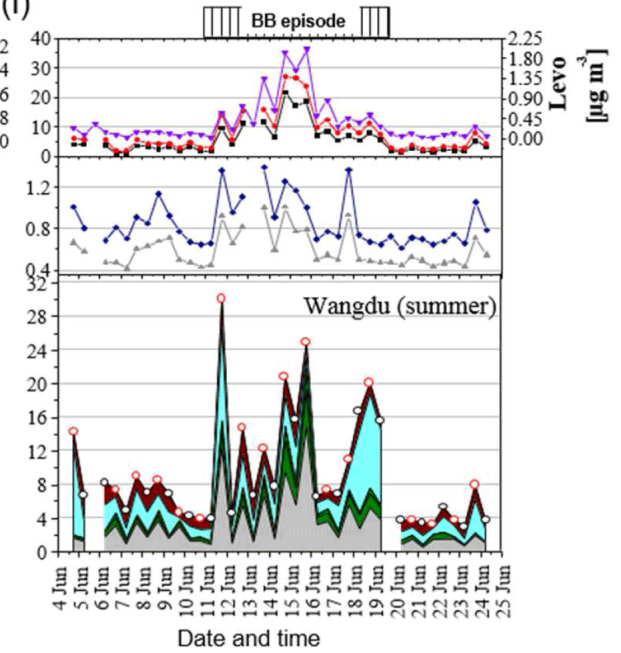

Figure 1. Temporal variation of the concentrations of nitrated aromatic compounds and levoglucosan (Levo) at each measurement site (a-f) and their optical properties. The aqueous light absorption coefficient (Abs) and mass absorption efficiency (MAE) are given at $370 \mathrm{~nm}$ for acidic conditions (indicated by the subscript "A") and for alkaline conditions (indicated by the subscript "B"). 
(a)



(c)

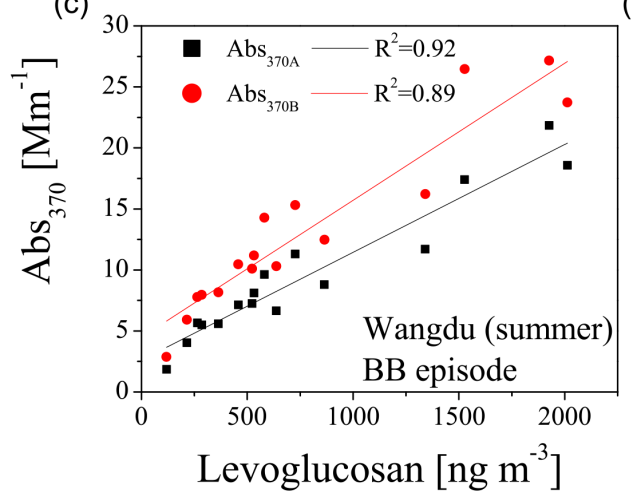

(b)

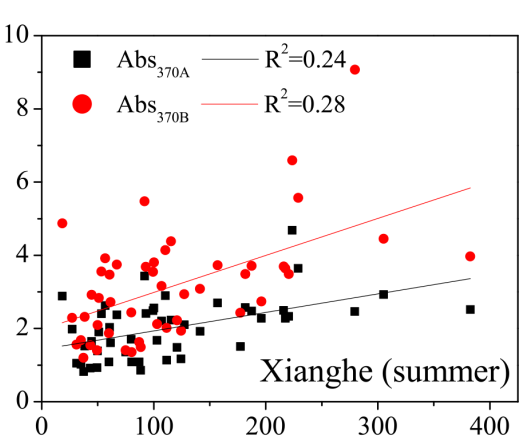

(d)

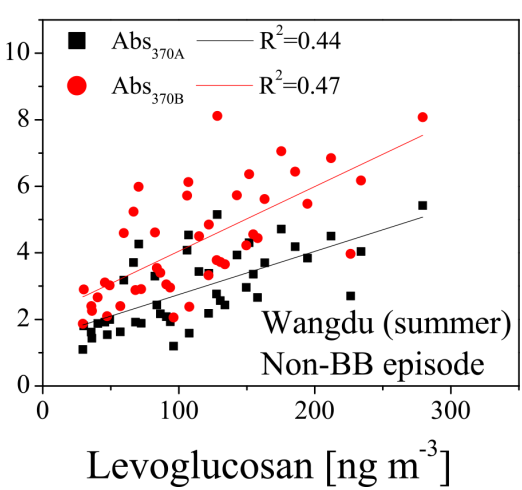

Figure 2. Scatter plot of the aqueous light absorption coefficient $\mathrm{Abs}_{370}$ with levoglucosan concentration for the campaigns (a) TROPOS (winter,), (b) Xianghe (summer), (c) Wangdu (summer, BB episode) and (d) Wangdu (summer, non-BB episode). Abs 370 is given for acidic conditions (indicated by the subscript "A", black squares) and for alkaline conditions (indicated by the subscript "B", red dots). Note different axis scales.

Due to the close relationship between MAE and Abs under alkaline and acidic conditions, only the values for the acidic conditions are discussed in the following section (Sect. 3.1.2), while both of them are always displayed in the figures and tables.

\subsubsection{Mass absorption efficiency and aqueous light absorption coefficient of water-soluble brown carbon}

The temporal evolution of $\mathrm{Abs}_{370}$ and $\mathrm{MAE}_{370}$ for each measurement site is shown in Fig. 1. The highest mean $\mathrm{MAE}_{370 \mathrm{~A}}$ values were found for the campaigns Melpitz (winter, $0.86 \pm 0.33 \mathrm{~m}^{2} \mathrm{~g}^{-1}$ ) and TROPOS (winter, $0.84 \pm 0.20 \mathrm{~m}^{2} \mathrm{~g}^{-1}$ ) followed by Wangdu (summer, $0.55 \pm 0.15 \mathrm{~m}^{2} \mathrm{~g}^{-1}$ ) and Xianghe (summer, $0.38 \pm 0.06 \mathrm{~m}^{2} \mathrm{~g}^{-1}$ ). The lowest values were observed under summer conditions in Germany, where the values for the Melpitz (summer) campaign slightly exceeded the $\mathrm{MAE}_{370 \mathrm{~A}}$ observed at the Waldstein (summer) campaign $\left(0.22 \pm 0.03 \mathrm{~m}^{2} \mathrm{~g}^{-1}\right.$ over $\left.0.17 \pm 0.03 \mathrm{~m}^{2} \mathrm{~g}^{-1}\right)$. Measured $\mathrm{MAE}_{370 \mathrm{~A}}$ values for China are in the same range or slightly lower than values reported in other studies. For instance, several studies were conducted in Beijing in summer, where Cheng et al. (2011) determined an average MAE of $0.7 \mathrm{~m}^{2} \mathrm{~g}^{-1}$, Du et al. (2014) found $0.5 \mathrm{~m}^{2} \mathrm{~g}^{-1}$ and Yan et al. (2015) observed $0.7 \mathrm{~m}^{2} \mathrm{~g}^{-1}$ (all values determined at $365 \mathrm{~nm}$ ). The findings for the TROPOS (winter) and Melpitz (winter) campaigns suggest regional behavior and are comparable to observed MAEs from urban sites in the US (Hecobian et al. (2010), 0.47-0.87 $\mathrm{m}^{2} \mathrm{~g}^{-1}$, annual mean, determined at $365 \mathrm{~nm}$ ). Low MAE values, similar to the observed MAEs at the Melpitz (summer) and Waldstein (summer) campaigns, have been found at urban and rural sites in the US $\left(0.21\right.$ and $0.12 \mathrm{~m}^{2} \mathrm{~g}^{-1}$, respectively, determined at $365 \mathrm{~nm}$ ) when the concentration of levoglucosan was low $\left(<50 \mathrm{ng} \mathrm{m}^{-3}\right)$. Although the average $\mathrm{Abs}_{370 \mathrm{~A}}$ is similar for the campaigns of Wangdu (summer), TROPOS (winter) and Melpitz (winter) $\left(4.64,3.92\right.$ and $4.13 \mathrm{Mm}^{-1}$, respectively), the observed mean $\mathrm{MAE}_{370 \mathrm{~A}}$ for the Wangdu (summer) campaign is lower, indicating that despite higher concentrations of OC and WSOC during the Wangdu (summer) campaign (see Table S3), fewer light-absorbing compounds were present.

A correlation between levoglucosan and $\mathrm{Abs}_{370}$ was found during the TROPOS (winter) campaign $\left(R^{2}=0.8\right)$ and during the BB episode of the Wangdu (summer) campaign $\left(R^{2}=0.9\right)$, when BB aerosol was abundant (see Fig. 2). This correlation suggests that BB aerosol is a major contributor to the aqueous extract light absorption. The connection between $\mathrm{BB}$ and light-absorbing $\mathrm{BrC}$ was also observed in a 

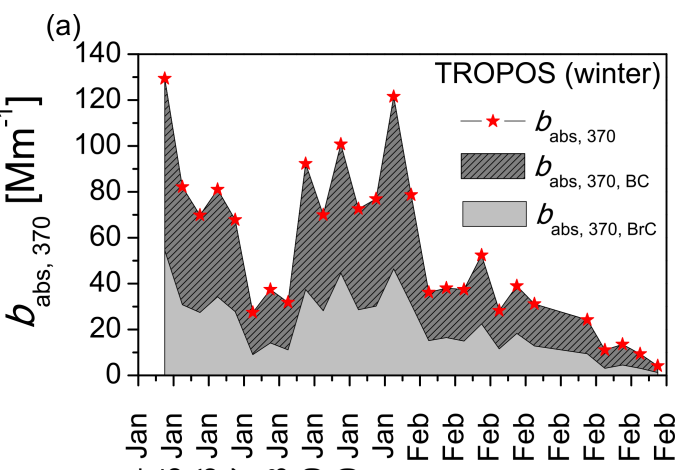

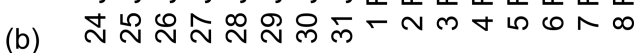

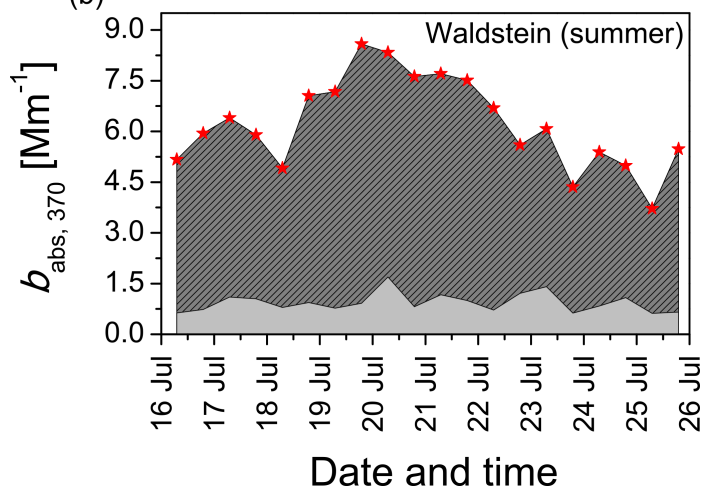

Figure 3. Temporal evolution of the particulate light absorption coefficient $b_{\text {abs }}$ at $370 \mathrm{~nm}$ derived from the aethalometer measurements during (a) the TROPOS (winter) campaign and (b) the Waldstein (summer) campaign. The fractions of black carbon (dark grey area) and brown carbon (light grey area) to the total measured $b_{\mathrm{abs}}$ were calculated as described in Eq. (2).

number of other studies (e.g., Desyaterik et al., 2013; Hoffer et al., 2006; Lack et al., 2013; Mohr et al., 2013). During non-BB episodes of the Wangdu (summer) campaign and the Xianghe (summer) campaign, only a weak or no correlation at all was observed between levoglucosan and $\mathrm{Abs}_{370}$ (see Fig. 2). This indicates the presence of sources for lightabsorbing compounds other than BB aerosols. A decay of levoglucosan more rapid than the decay of NACs might also be a cause for this observation (Hoffmann et al., 2010).

Regarding seasonal differences, the aqueous extract light absorption was much lower in summer compared to winter samples. This is a general trend, observed at many measurement sites (e.g., Du et al., 2014; Hecobian et al., 2010; Kim et al., 2016). Kim et al. (2016) suggested that this is either because the amount of emitted $\mathrm{BrC}$ is much higher during winter or that summer $\mathrm{BrC}$ is less water soluble. By comparing aqueous extract light absorption to ambient particle light absorption measurements, this issue will be further explored and discussed in the following section.

\subsubsection{Particulate light absorption coefficient and absorption Ångström exponent of particulate brown carbon}

The temporal evolution of the measured particulate light absorption coefficient $b_{\mathrm{abs}}$ at $370 \mathrm{~nm}$ as well as the determined contributions of particulate $\mathrm{BrC}$ and $\mathrm{BC}$ to the light absorption at $370 \mathrm{~nm}$ are shown in Fig. 3. Normalizing the determined $b_{\text {abs }}$ for particulate $\mathrm{BrC}$ by the according $\mathrm{OC}$ content gives the mass absorption efficiency for $\mathrm{BrC}$

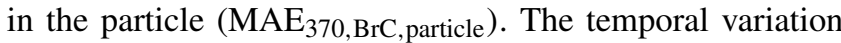

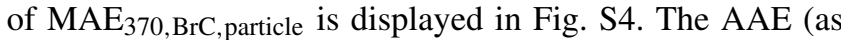
campaign average) obtained by fitting over all aethalometer wavelengths was $1.5 \pm 0.1$ and $1.2 \pm 0.3$ for the campaigns TROPOS (winter) and Waldstein (summer), respectively. An AAE close to 1 indicates that $\mathrm{BC}$ is the dominant species (Kirchstetter et al., 2004). The increased AAE values indicate that BrC plays a larger role for the TROPOS (winter) campaign than for the Waldstein (summer) campaign, where its contribution is minor.

During the BB influenced TROPOS (winter) campaign, the mean total $b_{\text {abs } 370}$ was $54 \mathrm{Mm}^{-1}$. Particulate $\mathrm{BrC}$ contributed about $40 \%$ to the overall light absorption at $370 \mathrm{~nm}$

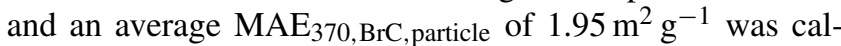
culated. The influence of BB on the light absorption of ambient particles has also been observed in other studies. For instance, Kirchstetter and Thatcher (2012) estimated that the contribution of $\mathrm{BrC}$ to the light absorption of wood smoke is $49 \%$ below $400 \mathrm{~nm}$ from samples collected in wintertime California (USA). Mohr et al. (2013) found a BrC contribution of $46 \%$ to $b_{\mathrm{abs}, 370}$ at a UK site that was highly influenced by $\mathrm{BB}$. Our findings on the contribution of $\mathrm{BrC}$ to $b_{\mathrm{abs}}, 370$ during the TROPOS (winter) campaign are consistent with these earlier measurements. The light absorption was observed to be higher for easterly air masses than those from the west, a trend also seen in the NAC concentrations of the TROPOS (winter) campaign (see Sect. 3.2). Easterly winds were often accompanied by lower temperatures or thermal inversion layers or both. Therefore, higher concentrations of light-absorbing compounds (and higher particulate light absorption) might be a result of both increased emissions (locally and in the source region) and lower dispersion of absorbing pollutants due to the thermal inversion layer.

In contrast, the light absorption of aerosol particles was much lower during the Waldstein (summer) campaign with a mean total $b_{\mathrm{abs}, 370}$ of $6 \mathrm{Mm}^{-1}$, a $\mathrm{MAE}_{370, \mathrm{BrC} \text {, particle of }}$ $0.21 \mathrm{~m}^{2} \mathrm{~g}^{-1}$ and a $\mathrm{BrC}$ contribution to the particulate light absorption of about $15 \%$ at $370 \mathrm{~nm}$. The measurements at Waldstein (which is surrounded by a mixed forest) were carried out in a sunny summer period when high biogenic emissions would strongly influence the results. Several laboratory studies have shown that the formation of lightabsorbing compounds from biogenic precursors is negligible (e.g., P. F. Liu et al., 2013; Nakayama et al., 2010; Song et al., 2013). However, a few studies have suggested that $\mathrm{BrC}$ 
might be formed in the presence of high ammonia concentrations (Flores et al., 2014; Updyke et al., 2012) or from isoprene epoxydiols (IEPOX; Lin et al., 2014). Findings from field measurements in the Amazon Basin confirmed that the light absorption by biogenic aerosol is much lower than the light absorption of BB aerosols or BC (Rizzo et al., 2011). Compared to the TROPOS (winter) campaign, $b_{\mathrm{abs}}$ for $\mathrm{BrC}$ is very small for the Waldstein (summer) campaign, with an average of $0.94 \mathrm{Mm}^{-1}$ compared to $21.8 \mathrm{Mm}^{-1}$. Our findings corroborate those of Rizzo et al. (2011) and laboratory studies stating that biogenic aerosols alone produce only small amounts of light-absorbing compounds.

The relative contribution of light-absorbing WSOC to particulate light absorption can be estimated by applying a conversion factor. Based on Mie theory calculations, J. Liu et al. (2013) suggested a factor of 2 to convert the aqueous extract light absorption coefficient (Abs) into the particulate light absorption coefficient $\left(b_{\text {abs }}\right)$. The temporal variation of the fraction of the converted $\mathrm{Abs}_{370}$ to the particulate $\mathrm{BrC}$ light absorption is given in Fig. S4. For our data, a good agreement between the Waldstein (summer) average $\operatorname{Abs}_{370 \mathrm{~A}}\left(0.51 \mathrm{Mm}^{-1} \times 2\right)$ and the Waldstein (summer) average $b_{\text {abs, } 370, \operatorname{BrC}}\left(0.94 \mathrm{Mm}^{-1}\right)$ was achieved, suggesting that the observed particulate light absorption is mainly associated with water-soluble compounds during this campaign. For the TROPOS (winter) campaign, doubling the average $\mathrm{Abs}_{370 \mathrm{~A}}$ gives a value of $7.8 \mathrm{Mm}^{-1}$, which is still much lower than the average $b_{\mathrm{abs}, 370, \mathrm{BrC}}\left(21.8 \mathrm{Mm}^{-1}\right)$. Thus, a large fraction of non-water-soluble OC likely exists as well, which is highly light absorbing at $370 \mathrm{~nm}$.

\subsection{Concentrations of nitrated aromatic compounds under different atmospheric conditions}

This section presents an overview and a comparison of the NAC concentrations for all campaigns. Table 3 summarizes the measured concentrations in comparison with other studies at similar locations. The results of the temporal variation of the target compounds for each campaign are displayed in Fig. 1.

A general concentration trend of $4 \mathrm{NP}>3 \mathrm{M} 4 \mathrm{NP}>2 \mathrm{M} 4 \mathrm{NP}$ $>2,6 \mathrm{DM} 4 \mathrm{NP}>2,4 \mathrm{DNP}>3,4 \mathrm{DNP}$ and $3 \mathrm{NSA}>5 \mathrm{NSA}$ was observed for all campaigns of the present study and is in good agreement with findings from most other studies. Regarding the sum of NPs, the mean concentrations were highest during the TROPOS (winter) campaign $\left(14.0 \mathrm{ng} \mathrm{m}^{-3}\right)$ followed by the Melpitz (winter) campaign $\left(11.1 \mathrm{ng} \mathrm{m}^{-3}\right)$. These concentrations are a factor of 3 to 10 higher than those observed during the campaigns Wangdu (summer) and Xianghe (summer) (4.4 and $1.4 \mathrm{ng} \mathrm{m}^{-3}$, respectively). During the Melpitz (summer) campaign, the NP concentration was 100 times lower (average of $0.1 \mathrm{ng} \mathrm{m}^{-3}$ ) than during the Melpitz (winter) campaign. For the sum of NSAs, the highest mean concentrations were found at the Wangdu (summer) campaign $\left(4.8 \mathrm{ng} \mathrm{m}^{-3}\right)$ followed by the campaigns Xianghe (summer) and TROPOS (winter) (average of $2.2 \mathrm{ng} \mathrm{m}^{-3}$, each). Average concentrations for NSAs of $\leq 1 \mathrm{ng} \mathrm{m}^{-3}$ were observed at the campaigns Melpitz (winter, $1.0 \mathrm{ng} \mathrm{m}^{-3}$ ), Waldstein (summer, $0.4 \mathrm{ng} \mathrm{m}^{-3}$ ) and Melpitz (summer, $0.2 \mathrm{ng} \mathrm{m}^{-3}$ ).

A clear seasonality can be seen in the data from the German sites. The observed concentrations of the different species are generally lower in summer than in winter because the sources of NACs are stronger during winter and generally connected to polluted air, as discussed in the Sect. 1.

The campaigns Melpitz (winter) and TROPOS (winter) were carried out in the same period and the two sites are directly comparable due to their geographic proximity. Concentrations of the NACs are in the same range at both sites and show a common pattern. Two periods with concentration maxima were found. The first period occurred around 25 January and the second peak was around 30 January 2014 (see Fig. 1a and b). Both periods are characterized by prevailing easterly winds and shorter mean lengths of $96 \mathrm{~h}$ back trajectories. In contrast, air masses during other periods originated from the southwest and had longer trajectories and increased residence times over the Atlantic Ocean. Higher concentrations of PM and many of its constituents with easterly winds are often observed at Melpitz (Spindler et al., 2010). The long residence time above the continent results in increased concentrations of pollutants in those air masses. Furthermore, as described in Sect. 3.1.3, the temperature was generally lower when the air mass originated from the east, which likely led to higher emissions from residential heating both locally and in the air mass source regions.

The campaigns Melpitz (summer) and Waldstein (summer) were also conducted in the same time period. The concentrations of NSAs are comparable at both sites (0.01$0.51 \mathrm{ng} \mathrm{m}^{-3}$ ) and are very low compared to the winter measurements. NPs were not analyzed from the Waldstein (summer) campaign as explained above.

Day and night samples were collected during the campaigns TROPOS (winter), Waldstein (summer), Xianghe (summer) and Wangdu (summer). Nighttime concentrations of the sum of NACs were found to be slightly higher than during the day (not statistically significant at $95 \%$ confidence level). The lower daytime concentrations are probably caused by the higher boundary layer heights during the day, i.e., dilution effects, and/or lower emission/formations rates during daytime or photolysis processes.

The sum of all target compounds at the TROPOS (winter) campaign was only weakly correlated with levoglucosan $\left(R^{2}=0.47\right.$, Fig. S5), indicating that BB was not the dominant source of NACs during the campaign. As mentioned above, the formation or decay processes of levoglucosan and NACs might be very different, which resulted in no correlation of those species. It is also known that the sources of NACs are very diverse (see Sect. 1).

At the Wangdu (summer) campaign, a BB episode was observed between 11 June and 19 June (see Fig. 1f), indicated by a peak in measured levoglucosan concentrations. During 


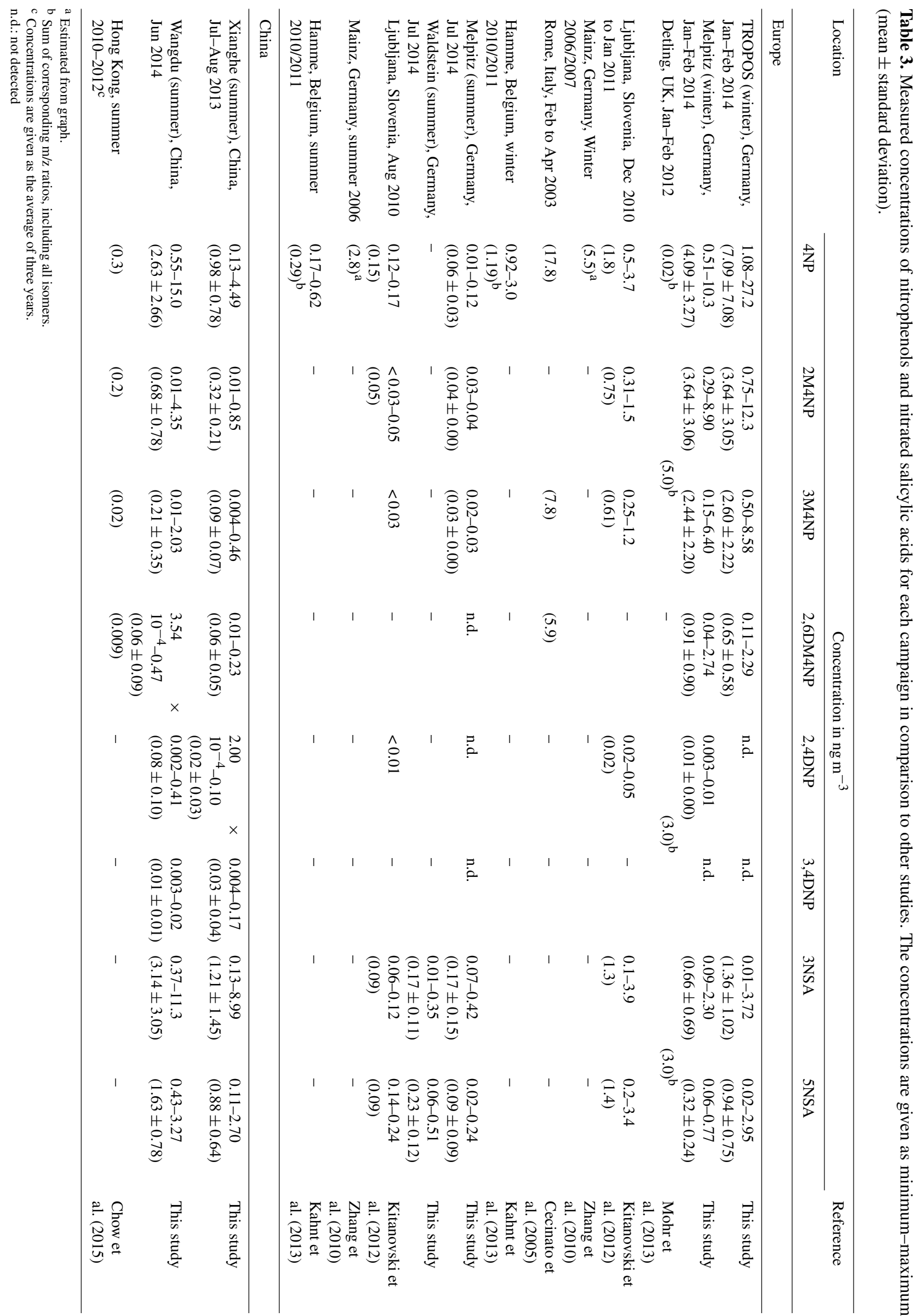


that period, increased concentrations of NACs were found. Although the NAC concentration generally increased with increasing levoglucosan concentration, no clear connection between NACs and BB aerosols was found. For the Xianghe (summer) campaign, levoglucosan concentrations (average of $109 \mathrm{ng} \mathrm{m}^{-3}$ ) were lower than for the Wangdu (summer) or TROPOS (winter) campaign, suggesting that BB played a minor role at this site during the time of measurements. No correlation was found between the sum of NACs and levoglucosan. This implies that BB was neither the major source of NACs in the Wangdu (summer) nor in the Xianghe (summer) campaign. It was found that NACs can be a product of the photochemical processing of anthropogenic volatile organic compounds (Jaoui et al., 2008), which might be a possible source for NACs at the Chinese sites besides BB.

NACs seem to be ubiquitous and are found at each site in measurable amounts although they are highly variable at the different measurement sites. The sum of NAC concentrations at the different campaigns followed the order TROPOS (winter) $>$ Melpitz (winter) $>$ Wangdu (summer) $>$ Xianghe (summer) $>$ Waldstein (summer) $>$ Melpitz (summer). This trend might be considered surprising, since the average $\mathrm{PM}_{10}$ and $\mathrm{OC}$ values were higher at the Chinese sites than at the German sites (see Table S3). However, the seasonality and influence of $\mathrm{BB}$ aerosol seem to play a large role in the NAC concentration resulting in lower concentrations at the Chinese summer sites than at the German winter sites.

\subsection{Contribution of nitrated aromatic compounds to water-soluble and particulate brown carbon}

In this section, the contribution of NACs to the aqueous extract light absorption and then the contribution of NACs to the particulate $\mathrm{BrC}$ light absorption are discussed. The relative contribution of NACs to $\mathrm{Abs}_{370}$ is shown in Fig. 4 together with the contribution of NACs to the WSOC concentration. Table 2 summarizes the contribution of NSAs and NPs to aqueous extract light absorption (Abs) and particulate $\mathrm{BrC}$ light absorption $\left(b_{\mathrm{abs}}\right)$. The focus is on the relative contribution to the aqueous extract light absorption at the wavelength of $370 \mathrm{~nm}$ to match the $370 \mathrm{~nm}$ channel of the aethalometer. To give additional information, the relative contribution of NACs to Abs (acidic conditions) over a spectral range of 300 to $500 \mathrm{~nm}$ is presented in Fig. 5 as their campaign averages.

The relative NAC contribution to $\mathrm{Abs}_{370}$ varied greatly across the different sites, ranging from 0.02 to $4.41 \%$ for acidic conditions and from 0.02 to $9.86 \%$ for alkaline conditions. This result likely reflects the dependence of NAC source strength on location and seasonality. The maximum contribution of NACs to $\mathrm{Abs}_{370}$ was found for the TROPOS (winter) campaign. The contribution of NACs to Abs 370 was low for the campaigns Waldstein (summer) and Melpitz (summer). For the Waldstein (summer) campaign, a mean contribution of $0.15 \%$ (acidic) or $0.13 \%$ (alkaline) was ob-

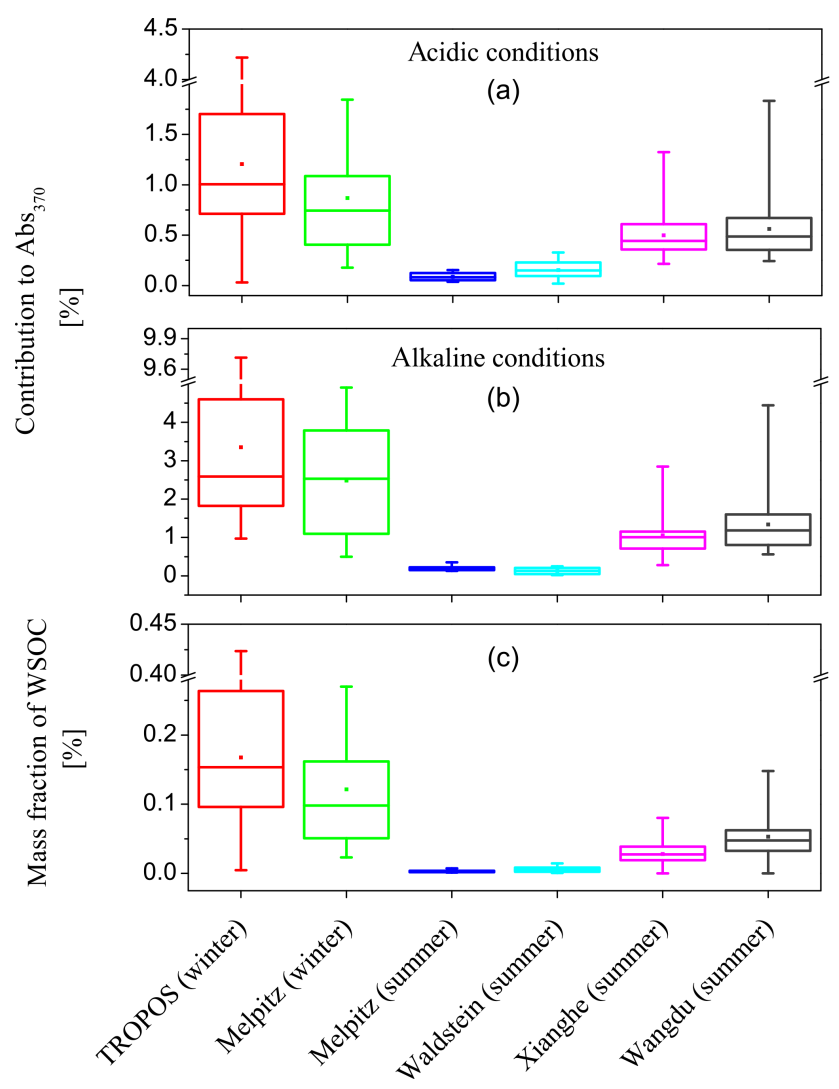

Figure 4. Top and center: contribution of the sum of NACs to the aqueous extract light absorption at each site under acidic (a) and alkaline (b) conditions. Bottom: mass contributions of the sum of NACs to the WSOC (c).

served. Average values of $0.13 \%$ (acidic) and $0.24 \%$ (alkaline) were obtained from the Melpitz (summer) campaign. This result is not surprising due to the low influence of $\mathrm{BB}$ aerosols or traffic and thus low NAC concentrations. A recent study by Nguyen et al. (2013) suggested the formation of $\mathrm{BrC}$ from ketoaldehydes derived from biogenic monoterpenes in the presence of ammonium ions. Thus, this reaction may play a role in regions with higher influence of biogenic emissions and might be one explanation for the observed absorption at the Melpitz (summer) and Waldstein (summer) campaigns. The formed species were suggested to consist of conjugated aldol condensates, secondary imines and nitrogen containing heterocycles, The results for the Xianghe (summer) and Wangdu (summer) campaigns are about half the values of the TROPOS (winter) or Melpitz (winter) campaigns. This shows that NACs in the present study had a much higher impact on the light absorption properties during the German winter campaigns than during the Chinese summer campaigns and indicates that other compounds play a larger role in particle light absorption at the Chinese sites. More studies are needed to resolve the molecular identity and abundance of these light-absorbing compounds. 
The relative contribution of NACs to Abs is wavelength dependent. Under acidic conditions, the contribution of NACs to the aqueous extract light absorption increases towards lower wavelength, reaching a maximum that was found to generally lie in the range of $330-350 \mathrm{~nm}$ (see Fig. 5). Moreover, it can be seen that maximum values differ for individual compounds. Under alkaline conditions, this maximum shifts towards the range of $400-420 \mathrm{~nm}$ (see Fig. S6). As stated above, the results for acidic conditions are likely to be more atmospherically relevant. Therefore, a higher influence of NACs towards shorter wavelengths suggests that they can be more important in terms of their influence on atmospheric photochemistry, e.g., $\mathrm{O}_{3}$ photolysis (Jacobson, 1999).

The relative mass contribution of NACs to the WSOC concentration at the different campaigns follows the same pattern as the contribution of NACs to the aqueous extract light absorption and also the same pattern as the NAC concentrations (see Sect. 3.2 and Fig. 4). The highest mass contributions of NACs were found during the TROPOS (winter) campaign followed by the Melpitz (winter) campaign, and lowest values were observed for the campaigns Waldstein (summer) and Melpitz (summer). The average mass contribution of NACs to WSOC is less than $0.2 \%$ at each site. In contrast, NACs have a mean contribution to aqueous extract light absorption of $1 \%$, which is a factor of 5 larger than their mass contribution to WSOC. Our results corroborate the findings of other studies, which show that even small amounts of light-absorbing compounds can significantly impact the light absorption properties of particles. As a result, a detailed investigation of the molecular composition of $\mathrm{BrC}$ is important (Kampf et al., 2012; Laskin et al., 2015).

The correlation between NAC concentrations and $\mathrm{Abs}_{370}$ for each campaign is displayed in Fig. 6. The correlation is good for the TROPOS (winter) and Melpitz (winter) campaign $\left(R^{2}=0.7\right.$, each) and weaker for the Wangdu (summer) campaign $\left(R^{2}=0.6\right)$. No correlation was found for the campaigns Xianghe (summer), Melpitz (summer) and Waldstein (summer). In general, the presence of high NAC concentrations also indicates higher values for $\mathrm{Abs}_{370}$ than at sites with lower NAC concentrations. However, due to the diverse sources and sinks (e.g., photobleaching, Zhao et al., 2015) of NACs and BrC, NACs cannot be considered as the only tracers for $\mathrm{BrC}$ for very different atmospheric conditions.

The average contribution of NACs to particulate $\mathrm{BrC}$ light absorption was found to be $0.10 \%$ for the Waldstein (summer) campaign and $0.25 \%$ for the TROPOS (winter) campaign for the protonated forms and 0.13 and $1.18 \%$, respectively, for their deprotonated forms. The contribution during the Waldstein (summer) campaign is similar for the aqueous extract and aerosol light absorption, which is consistent with the assumption discussed above that the observed light absorption is mostly derived from WSOC and no further waterinsoluble $\mathrm{BrC}$ was present at this site.
To the best of the author's knowledge, up to now only two other field studies have determined the contribution of individual compounds to $\mathrm{BrC}$ light absorption. Zhang et al. (2013) estimated the contribution of eight NACs to aqueous extract light absorption in Los Angeles to be about $4 \%$ at $365 \mathrm{~nm}$, while Mohr et al. (2013) estimated a NAC contribution of $4 \%$ to particulate $\mathrm{BrC}$ light absorption at $370 \mathrm{~nm}$ at a BB influenced site in the UK. The findings from Zhang et al. (2013) are in the same range as our findings for the TROPOS (winter) campaign (for $\mathrm{Abs}_{370}$ ), whereas the estimated contribution of NACs to particulate BrC light absorption by Mohr et al. (2013) is a factor of 16 larger than our observed contributions. One possible reason for this discrepancy is that the mean $b_{\mathrm{abs}, \mathrm{BrC}}$, measured in the present study is about twice as high as observed by Mohr et al. (2013) $\left(10 \mathrm{Mm}^{-1}\right)$ while the concentrations of NACs are in the same range in both studies. Moreover, Mohr et al. (2013) considered a different suite of NACs than the present study. Another important point is that the calculation by Mohr et al. (2013) used values based on the absorption maxima of the individual species, which usually lie below $370 \mathrm{~nm}$ (for their protonated form). In contrast, in the present study the molar extinction coefficient of each compound was directly determined at $370 \mathrm{~nm}$. When calculations were made based on the absorption maxima of protonated NACs, an average contribution to the particulate $\mathrm{BrC}$ light absorption of $1 \%$ was found for the present study, i.e., a factor of 4 higher than the calculation at $370 \mathrm{~nm}$.

\section{Conclusions}

In the present study, the contributions of eight NACs to the light absorption of aqueous particle extracts and particulate $\mathrm{BrC}$ were determined in Germany and China at five measurement sites under six different atmospheric conditions.

The effect of $\mathrm{pH}$ on the aqueous extracts light absorption was investigated. Absorption of extracts at $370 \mathrm{~nm}, \mathrm{Abs}_{370}$, increased by a factor of 1.4 and MAE by a factor of 1.6 when the $\mathrm{pH}$ was increased from 2 to 10 . A general seasonal trend of $\mathrm{MAE}_{370}$ and $\mathrm{Abs}_{370}$ being higher in winter than in summer was observed, which is in agreement with other studies. The MAE values during winter times impacted by BB in Germany exceeded those of the Chinese background stations during summer. Very low MAE and $b_{\mathrm{abs}, 370}$ were observed at the forest site Waldstein in summer, indicating that freshly emitted biogenic aerosols are only weakly absorbing. In contrast, a strong relationship was found between the light absorption properties and BB aerosol concentrations, corroborating findings from other studies. An average contribution of particulate $\mathrm{BrC}$ to $b_{\mathrm{abs}, 370}$ of $46 \%$ was observed during the TROPOS (winter) campaign and $15 \%$ during the Waldstein (summer) campaign. The AAE of particulate $\mathrm{BrC}$ was found to be 1.5 and 1.2 for the campaigns TROPOS (winter) and Waldstein (summer), respectively. 
Acidic conditions

(a)



(c)

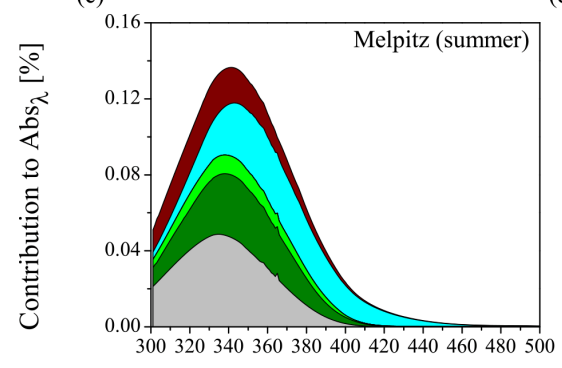

(e)

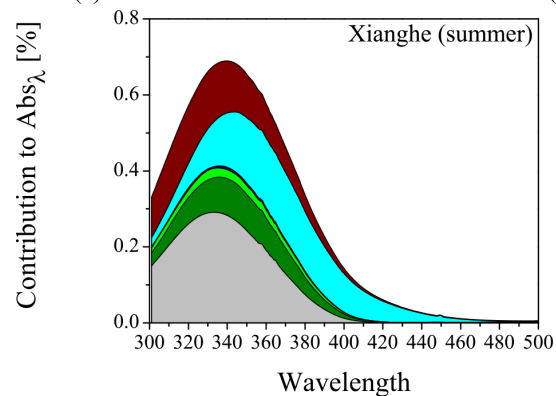

(b)

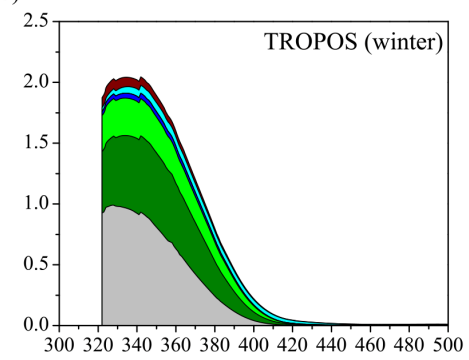

(d)

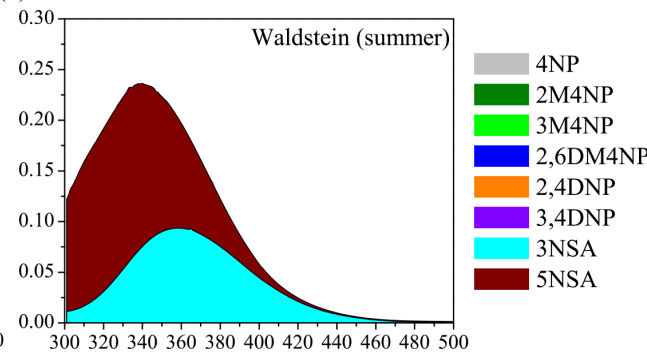

(f)

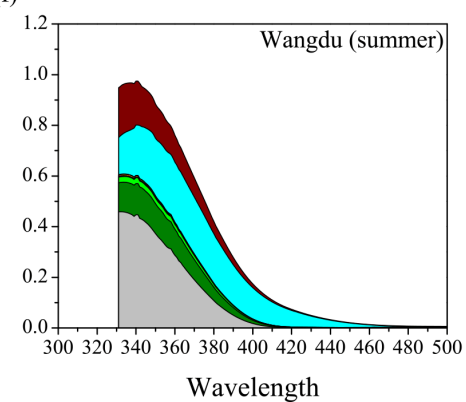

Figure 5. Relative contribution of NACs to $\mathrm{Abs}_{\lambda}$ over the spectral range of 300 to $500 \mathrm{~nm}$ for each measurement campaign (a-f) under acidic conditions. The data are presented as campaign averages. Due to instrumental issues, data for lower wavelengths are not always available.

The relative contribution of NACs to the aqueous extract light absorption was highly variable depending on the measurement site, ranging from 0.02 to $4.41 \%$ under acidic conditions and 0.02 to $9.86 \%$ under alkaline conditions. This indicates that the emission strength of light-absorbing compounds and the composition of $\mathrm{BrC}$ differed between the sites. In addition, the formation and decay processes might be very different in the respective environments. The mean contribution of NACs to the particulate $\mathrm{BrC}$ light absorption was $0.10 \%$ (acidic conditions) and $0.13 \%$ (alkaline conditions) during the Waldstein (summer) campaign and $0.23 \%$ (acidic conditions) and $1.15 \%$ (alkaline conditions) during the TROPOS (winter) campaign. A correlation between the NAC concentration and $\mathrm{Abs}_{370}$ was observed during the campaigns TROPOS (winter) and Melpitz (winter), at other sites the correlation was weak or nonexistent.

The mass contribution of NACs to WSOC was 5 times lower than their contribution to the aqueous extract light absorption. This corroborates conclusions of other studies that even small amounts of light-absorbing compounds can have a disproportionately high impact on the aerosol light absorption properties (Kampf et al., 2012).

Field studies on the molecular composition of $\mathrm{BrC}$ are still scarce, especially for sites that have no or little influence of BB aerosols. Therefore, more efforts are needed to assess $\mathrm{BrC}$ on a molecular level, since a deeper knowledge of the present light-absorbing compounds can improve the understanding and prediction of $\mathrm{BrC}$ aging processes and its radiative forcing (Laskin et al., 2015). A further investigation of $\mathrm{BrC}$ compounds may also result in finding tracer compounds for specific $\mathrm{BrC}$ sources.

\section{Data availability}

The dataset is available upon request to the corresponding author. 
(a)

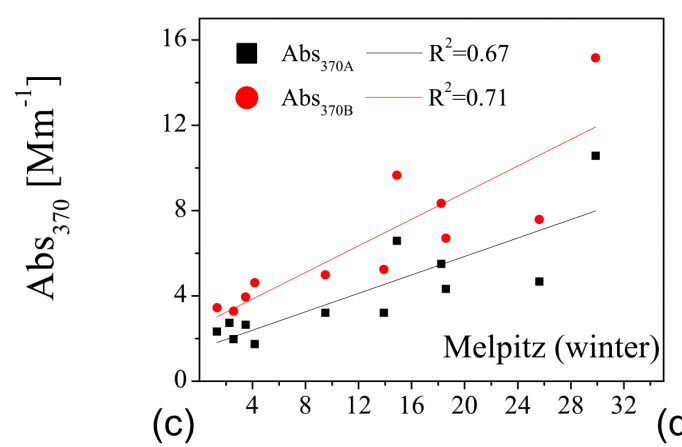

(b)

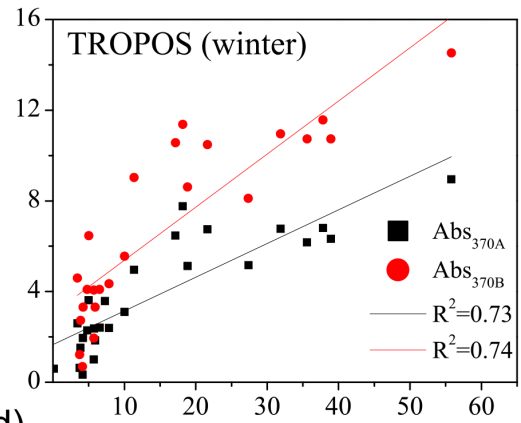

(d)

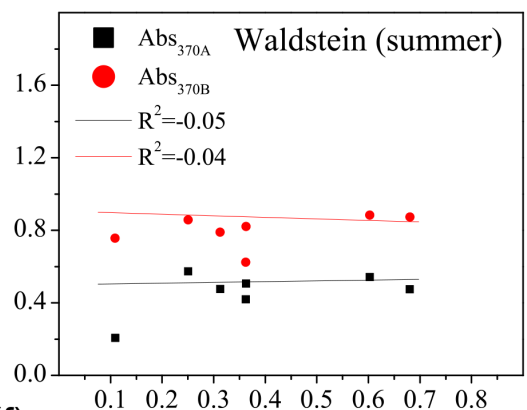

(f)
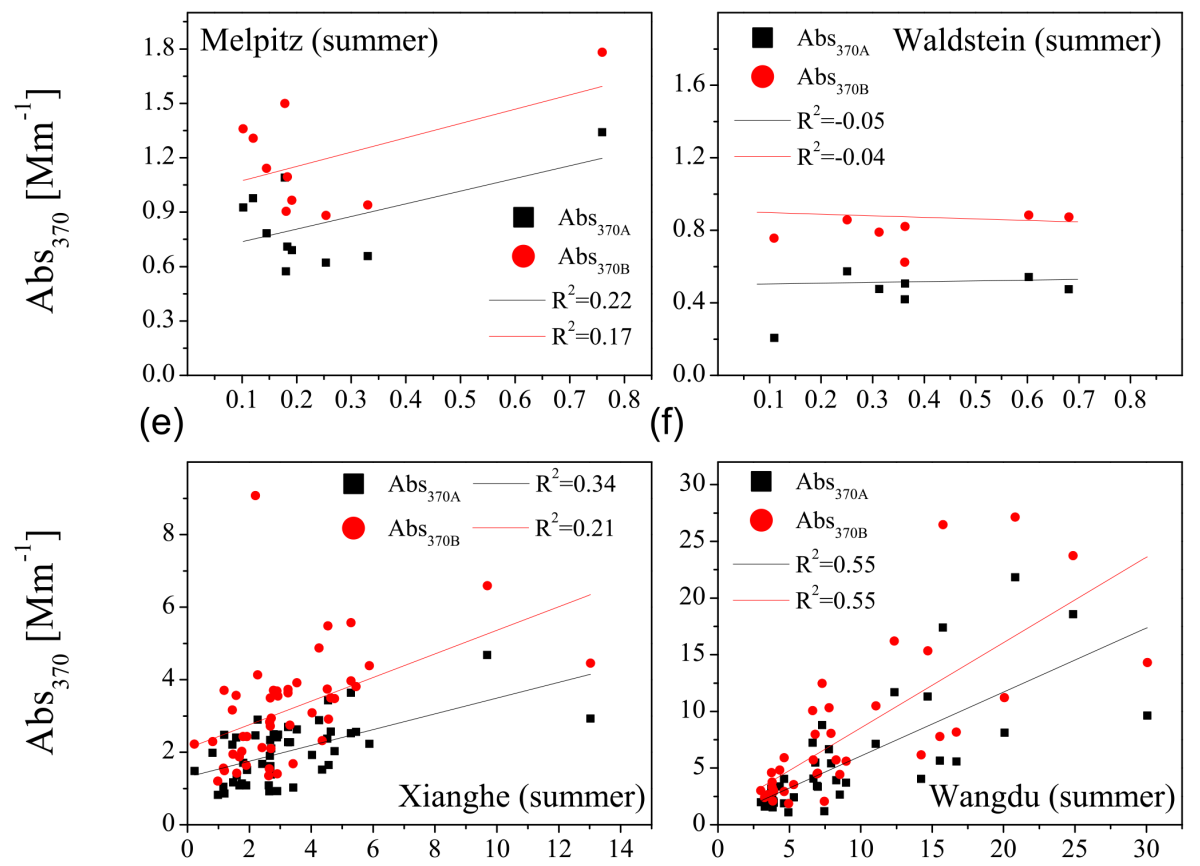

Concentration NACs [ng m${ }^{-3}$ ]

Figure 6. Scatter plots of the sum of NACs concentrations with the aqueous light absorption coefficient (Abs 370$)$ for each campaign: (a) Melpitz (winter), (b) TROPOS (winter,), (c) Melpitz (summer), (d) Waldstein (summer), (e) Xianghe (summer) and (f) Wangdu (summer). The aqueous light absorption coefficient is given at $370 \mathrm{~nm}$ for acidic conditions (indicated by the subscript "A", black squares) and for alkaline conditions (indicated by the subscript "B", red dots).

The Supplement related to this article is available online at doi:10.5194/acp-17-1653-2017-supplement.

Competing interests. The authors declare that they have no conflict of interest.

Acknowledgements. This research was part of the "BranKo" project, supported by the German Research Foundation (DFG) under contracts PI 1102/3-1 and HE 3086/26-1. Traveling and accommodation costs for CAREBeijing-NCP 2013 and
CAREBeijing-NCP 2014 were funded by the EU project AMIS 295132 and the Sino-German Science Center project no. GZ663, respectively. The authors would like to thank Gerald Spindler and Yoshiteru Iinuma for providing OC/EC and levoglucosan concentrations, respectively. Dean Venables is thanked for language corrections and providing useful suggestions. The analytical work of the technical staff in the laboratories of TROPOS ACD is also acknowledged. G. Močnik is employed by the company Aerosol d.o.o. where the aethalometer AE33 was developed and is manufactured.

Edited by: A. Laskin

Reviewed by: three anonymous referees 


\section{References}

Alif, A., Boule, P., and Lemaire, J.: Photochemical Behavior of 4-Nitrophenol in Aqueous-Solution, Chemosphere, 16, 22132223, doi:10.1016/0045-6535(87)90280-3, 1987.

Alif, A., Boule, P., and Lemaire, J.: Photochemistry and Environment .12. Phototransformation of 3-Nitrophenol in Aqueous-Solution, J. Photoch. Photobio. A, 50, 331-342, doi:10.1016/1010-6030(90)87022-4, 1990.

Alif, A., Pilichowski, J. F., and Boule, P.: Photochemistry and Environment .13. Phototransformation of 2-Nitrophenol in Aqueous-Solution, J. Photoch. Photobio. A, 59, 209-219, doi:10.1016/1010-6030(91)87009-K, 1991.

Andreae, M. O. and Gelencsér, A.: Black carbon or brown carbon? The nature of light-absorbing carbonaceous aerosols, Atmos. Chem. Phys., 6, 3131-3148, doi:10.5194/acp-6-3131-2006, 2006.

Baduel, C., Voisin, D., and Jaffrezo, J.-L.: Seasonal variations of concentrations and optical properties of water soluble HULIS collected in urban environments, Atmos. Chem. Phys., 10, 40854095, doi:10.5194/acp-10-4085-2010, 2010.

Bahadur, R., Praveen, P. S., Xu, Y. Y., and Ramanathan, V.: Solar absorption by elemental and brown carbon determined from spectral observations, P. Natl. Acad. Sci. USA, 109, 17366-17371, doi:10.1073/pnas.1205910109, 2012.

Bolzacchini, E., Bruschi, M., Hjorth, J., Meinardi, S., Orlandi, M., Rindone, B., and Rosenbohm, E.: Gas-phase reaction of phenol with $\mathrm{NO}_{3}$, Environ. Sci. Technol., 35, 1791-1797, doi:10.1021/es001290m, 2001.

Bond, T. C.: Spectral dependence of visible light absorption by carbonaceous particles emitted from coal combustion, Geophys. Res. Lett., 28, 4075-4078, doi:10.1029/2001g1013652, 2001.

Bosch, C., Andersson, A., Kirillova, E. N., Budhavant, K., Tiwari, S., Praveen, P. S., Russell, L. M., Beres, N. D., Ramanathan, V., and Gustafsson, O.: Source-diagnostic dual-isotope composition and optical properties of water-soluble organic carbon and elemental carbon in the South Asian outflow intercepted over the Indian Ocean, J. Geophys. Res., 119, 11743-11759, doi:10.1002/2014JD022127, 2014.

Cavalli, F., Viana, M., Yttri, K. E., Genberg, J., and Putaud, J.-P.: Toward a standardised thermal-optical protocol for measuring atmospheric organic and elemental carbon: the EUSAAR protocol, Atmos. Meas. Tech., 3, 79-89, doi:10.5194/amt-3-79-2010, 2010.

Cecinato, A., Di Palo, V., Pomata, D., Tomasi Sciano, M. C., and Possanzini, M.: Measurement of phase-distributed nitrophenols in Rome ambient air, Chemosphere, 59, 679-683, doi:10.1016/j.chemosphere.2004.10.045, 2005.

Chen, Y. and Bond, T. C.: Light absorption by organic carbon from wood combustion, Atmos. Chem. Phys., 10, 1773-1787, doi:10.5194/acp-10-1773-2010, 2010.

Cheng, Y., He, K.-B., Zheng, M., Duan, F.-K., Du, Z.-Y., Ma, Y.L., Tan, J.-H., Yang, F.-M., Liu, J.-M., Zhang, X.-L., Weber, R. J., Bergin, M. H., and Russell, A. G.: Mass absorption efficiency of elemental carbon and water-soluble organic carbon in Beijing, China, Atmos. Chem. Phys., 11, 11497-11510, doi:10.5194/acp11-11497-2011, 2011.

Cheng, Y., He, K. B., Du, Z. Y., Engling, G., Liu, J. M., Ma, Y. L., Zheng, M., and Weber, R. J.: The characteristics of brown carbon aerosol during winter in Beijing, Atmos. Environ., 127, 355-364, doi:10.1016/j.atmosenv.2015.12.035, 2016.

Chow, K. S., Huang, X. H. H., and Yu, J. Z.: Quantification of nitroaromatic compounds in atmospheric fine particulate matter in Hong Kong over 3 years: field measurement evidence for secondary formation derived from biomass burning emissions, Environ. Chem., 13, 665-673, doi:10.1071/EN15174, 2015.

Desyaterik, Y., Sun, Y., Shen, X. H., Lee, T. Y., Wang, X. F., Wang, T., and Collett, J. L.: Speciation of "brown" carbon in cloud water impacted by agricultural biomass burning in eastern China, J. Geophys. Res., 118, 7389-7399, doi:10.1002/jgrd.50561, 2013.

Drinovec, L., Mocnik, G., Zotter, P., Prévôt, A. S. H., Ruckstuhl, C., Coz, E., Rupakheti, M., Sciare, J., Müller, T., Wiedensohler, A., and Hansen, A. D. A.: The "dual-spot" Aethalometer: an improved measurement of aerosol black carbon with realtime loading compensation, Atmos. Meas. Tech., 8, 1965-1979, doi:10.5194/amt-8-1965-2015, 2015.

Du, Z. Y., He, K. B., Cheng, Y., Duan, F. K., Ma, Y. L., Liu, J. M., Zhang, X. L., Zheng, M., and Weber, R.: A yearlong study of water-soluble organic carbon in Beijing II: Light absorption properties, Atmos. Environ., 89, 235-241, doi:10.1016/j.atmosenv.2014.02.022, 2014.

Duarte, R. M. B. O., Pio, C. A., and Duarte, A. C.: Spectroscopic study of the water-soluble organic matter isolated from atmospheric aerosols collected under different atmospheric conditions, Anal. Chim. Acta, 530, 7-14, doi:10.1016/j.aca.2004.08.049, 2005.

Feng, Y., Ramanathan, V., and Kotamarthi, V. R.: Brown carbon: a significant atmospheric absorber of solar radiation?, Atmos. Chem. Phys., 13, 8607-8621, doi:10.5194/acp-13-8607-2013, 2013.

Flores, J. M., Washenfelder, R. A., Adler, G., Lee, H. J., Segev, L., Laskin, J., Laskin, A., Nizkorodov, S. A., Brown, S. S., and Rudich, Y.: Complex refractive indices in the near-ultraviolet spectral region of biogenic secondary organic aerosol aged with ammonia, Phys. Chem. Chem. Phys., 16, 10629-10642, doi:10.1039/c4cp01009d, 2014.

Galloway, M. M., Chhabra, P. S., Chan, A. W. H., Surratt, J. D., Flagan, R. C., Seinfeld, J. H., and Keutsch, F. N.: Glyoxal uptake on ammonium sulphate seed aerosol: reaction products and reversibility of uptake under dark and irradiated conditions, Atmos. Chem. Phys., 9, 3331-3345, doi:10.5194/acp-9-3331-2009, 2009.

Gyawali, M., Arnott, W. P., Lewis, K., and Moosmüller, H.: In situ aerosol optics in Reno, NV, USA during and after the summer 2008 California wildfires and the influence of absorbing and non-absorbing organic coatings on spectral light absorption, Atmos. Chem. Phys., 9, 8007-8015, doi:10.5194/acp-9-8007-2009, 2009.

Hecobian, A., Zhang, X., Zheng, M., Frank, N., Edgerton, E. S., and Weber, R. J.: Water-Soluble Organic Aerosol material and the light-absorption characteristics of aqueous extracts measured over the Southeastern United States, Atmos. Chem. Phys., 10, 5965-5977, doi:10.5194/acp-10-5965-2010, 2010.

Hinrichs, R. Z., Buczek, P., and Trivedi, J. J.: Solar Absorption by Aerosol-Bound Nitrophenols Compared to Aqueous and Gaseous Nitrophenols, Environ. Sci. Technol., 50, 5661-5667, doi:10.1021/acs.est.6b00302, 2016. 
Hoffer, A., Gelencsér, A., Guyon, P., Kiss, G., Schmid, O., Frank, G. P., Artaxo, P., and Andreae, M. O.: Optical properties of humic-like substances (HULIS) in biomass-burning aerosols, Atmos. Chem. Phys., 6, 3563-3570, doi:10.5194/acp-6-3563-2006, 2006.

Hoffmann, D., Iinuma, Y., and Herrmann, H.: Development of a method for fast analysis of phenolic molecular markers in biomass burning particles using high performance liquid chromatography/atmospheric pressure chemical ionisation mass spectrometry, J. Chromatogr. A, 1143, 168-175, doi:10.1016/j.chroma.2007.01.035, 2007.

Hoffmann, D., Tilgner, A., Iinuma, Y., and Herrmann, H.: Atmospheric Stability of Levoglucosan: A Detailed Laboratory and Modeling Study, Environ. Sci. Technol., 44, 694-699, 2010.

Iinuma, Y., Brüggemann, E., Gnauk, T., Müller, K., Andreae, M. O., Helas, G., Parmar, R., and Herrmann, H.: Source characterization of biomass burning particles: The combustion of selected European conifers, African hardwood, savanna grass, and German and Indonesian peat, J. Geophys. Res., 112, D08209, doi:10.1029/2006JD007120, 2007.

Iinuma, Y., Engling, G., Puxbaum, H., and Herrmann, H.: A highly resolved anion-exchange chromatographic method for determination of saccharidic tracers for biomass combustion and primary bio-particles in atmospheric aerosol, Atmos. Environ., 43, 13671371, doi:10.1016/j.atmosenv.2008.11.020, 2009.

Iinuma, Y., Böge, O., Gräfe, R., and Herrmann, H.: Methylnitrocatechols: atmospheric tracer compounds for biomass burning secondary organic aerosols, Environ. Sci. Technol., 44, 8453-8459, doi:10.1021/Es102938a, 2010.

Jacobson, M. Z.: Isolating nitrated and aromatic aerosols and nitrated aromatic gases as sources of ultraviolet light absorption, J. Geophys. Res., 104, 3527-3542, doi:10.1029/1998jd100054, 1999.

Jaoui, M., Edney, E. O., Kleindienst, T. E., Lewandowski, M., Offenberg, J. H., Surratt, J. D., and Seinfeld, J. H.: Formation of secondary organic aerosol from irradiated $\alpha$-pinene/toluene/ $\mathrm{NO}_{x}$ mixtures and the effect of isoprene and sulfur dioxide, J. Geophys. Res., 113, D09303, doi:10.1029/2007JD009426, 2008.

Jo, D. S., Park, R. J., Lee, S., Kim, S.-W., and Zhang, X.: A global simulation of brown carbon: implications for photochemistry and direct radiative effect, Atmos. Chem. Phys., 16, 3413-3432, doi:10.5194/acp-16-3413-2016, 2016.

Kahnt, A., Behrouzi, S., Vermeylen, R., Shalamzari, M. S., Vercauteren, J., Roekens, E., Claeys, M., and Maenhaut, W.: Oneyear study of nitro-organic compounds and their relation to wood burning in PM10 aerosol from a rural site in Belgium, Atmos. Environ., 81, 561-568, doi:10.1016/j.atmosenv.2013.09.041, 2013.

Kampf, C. J., Jakob, R., and Hoffmann, T.: Identification and characterization of aging products in the glyoxal/ammonium sulfate system - implications for light-absorbing material in atmospheric aerosols, Atmos. Chem. Phys., 12, 6323-6333, doi:10.5194/acp-12-6323-2012, 2012.

Kecorius, S., Zhang, S., Wang, Z., Gross, J., Ma, N., Wu, Z., Ran, L., Hu, M., Wang, P., Ulevicius, V., and Wiedensohler, A.: Nocturnal Aerosol Particle Formation in the North China Plain, Lith. J. Phys., 55, 44-53, doi:10.3952/physics.v55i1.3057, 2015.

Kecorius, S., Ma, N., Teich, M., Zhang, S., Größ, J., Spindler, G., Müller, K., Iinuma, Y., van Pinxteren, D., Hu, M., Herrmann, H., and Wiedensohler, A.: Influence of biomass burning on mixing state of ultrafine particles in the North China Plain, Atmos. Environ., submitted, 2016.

Kim, H., Kim, J. Y., Jin, H. C., Lee, J. Y., and Lee, S. P.: Seasonal variations in the light-absorbing properties of water-soluble and insoluble organic aerosols in Seoul, Korea, Atmos. Environ., 129, 234-242, doi:10.1016/j.atmosenv.2016.01.042, 2016.

Kirchstetter, T. W. and Thatcher, T. L.: Contribution of organic carbon to wood smoke particulate matter absorption of solar radiation, Atmos. Chem. Phys., 12, 6067-6072, doi:10.5194/acp-126067-2012, 2012.

Kirchstetter, T. W., Novakov, T., and Hobbs, P. V.: Evidence that the spectral dependence of light absorption by aerosols is affected by organic carbon, J. Geophys. Res., 109, D21208, doi:10.1029/2004jd004999, 2004.

Kitanovski, Z., Grgic, I., Vermeylen, R., Claeys, M., and Maenhaut, W.: Liquid chromatography tandem mass spectrometry method for characterization of monoaromatic nitro-compounds in atmospheric particulate matter, J. Chromatogr. A, 1268, 35-43, doi:10.1016/j.chroma.2012.10.021, 2012.

Lack, D. A. and Langridge, J. M.: On the attribution of black and brown carbon light absorption using the Ångström exponent, Atmos. Chem. Phys., 13, 10535-10543, doi:10.5194/acp13-10535-2013, 2013.

Lack, D. A., Bahreini, R., Langridge, J. M., Gilman, J. B., and Middlebrook, A. M.: Brown carbon absorption linked to organic mass tracers in biomass burning particles, Atmos. Chem. Phys., 13, 2415-2422, doi:10.5194/acp-13-2415-2013, 2013.

Laskin, A., Laskin, J., and Nizkorodov, S. A.: Chemistry of atmospheric brown carbon, Chem. Rev., 115, 4335-4382, doi:10.1021/cr5006167, 2015.

Lin, P., Liu, J. M., Shilling, J. E., Kathmann, S. M., Laskin, J., and Laskin, A.: Molecular characterization of brown carbon $(\mathrm{BrC})$ chromophores in secondary organic aerosol generated from photo-oxidation of toluene, Phys. Chem. Chem. Phys., 17, 23312-23325, doi:10.1039/C5CP02563J, 2015a.

Lin, P., Laskin, J., Nizkorodov, S. A., and Laskin, A.: Revealing Brown Carbon Chromophores Produced in Reactions of Methylglyoxal with Ammonium Sulfate, Environ. Sci. Technol., 49, 14257-14266, doi:10.1021/acs.est.5b03608, 2015 b.

Lin, Y. H., Budisulistiorini, H., Chu, K., Siejack, R. A., Zhang, H. F., Riva, M., Zhang, Z. F., Gold, A., Kautzman, K. E., and Surratt, J. D.: Light-absorbing oligomer formation in secondary organic aerosol from reactive uptake of isoprene epoxydiols, Environ. Sci. Technol., 48, 12012-12021, doi:10.1021/es503142b, 2014.

Liu, J., Bergin, M., Guo, H., King, L., Kotra, N., Edgerton, E., and Weber, R. J.: Size-resolved measurements of brown carbon in water and methanol extracts and estimates of their contribution to ambient fine-particle light absorption, Atmos. Chem. Phys., 13, 12389-12404, doi:10.5194/acp-13-12389-2013, 2013.

Liu, J., Scheuer, E., Dibb, J., Diskin, G. S., Ziemba, L. D., Thornhill, K. L., Anderson, B. E., Wisthaler, A., Mikoviny, T., Devi, J. J., Bergin, M., Perring, A. E., Markovic, M. Z., Schwarz, J. P., Campuzano-Jost, P., Day, D. A., Jimenez, J. L., and Weber, R. J.: Brown carbon aerosol in the North American continental troposphere: sources, abundance, and radiative forcing, Atmos. Chem. Phys., 15, 7841-7858, doi:10.5194/acp-15-7841-2015, 2015. 
Liu, P. F., Zhang, Y., and Martin, S. T.: Complex refractive indices of thin films of secondary organic materials by spectroscopic ellipsometry from 220 to $1200 \mathrm{~nm}$, Environ. Sci. Technol., 47, 13594-13601, doi:10.1021/es403411e, 2013.

Martinsson, J., Eriksson, A. C., Nielsen, I. E., Malmborg, V. B., Ahlberg, E., Andersen, C., Lindgren, R., Nystrom, R., Nordin, E. Z., Brune, W. H., Svenningsson, B., Swietlicki, E., Boman, C., and Pagels, J. H.: Impacts of Combustion Conditions and Photochemical Processing on the Light Absorption of Biomass Combustion Aerosol, Environ. Sci. Technol., 49, 14663-14671, doi:10.1021/acs.est.5b03205, 2015.

Mohr, C., Lopez-Hilfiker, F. D., Zotter, P., Prevot, A. S., Xu, L., Ng, N. L., Herndon, S. C., Williams, L. R., Franklin, J. P., Zahniser, M. S., Worsnop, D. R., Knighton, W. B., Aiken, A. C., Gorkowski, K. J., Dubey, M. K., Allan, J. D., and Thornton, J. A.: Contribution of nitrated phenols to wood burning brown carbon light absorption in Detling, United Kingdom during winter time, Environ. Sci. Technol., 47, 6316-6324, doi:10.1021/es400683v, 2013.

Moosmüller, H., Chakrabarty, R. K., and Arnott, W. P.: Aerosol light absorption and its measurement: A review, J. Quant. Spectrosc. Ra., 110, 844-878, doi:10.1016/j.jqsrt.2009.02.035, 2009.

Nakayama, T., Matsumi, Y., Sato, K., Imamura, T., Yamazaki, A., and Uchiyama, A.: Laboratory studies on optical properties of secondary organic aerosols generated during the photooxidation of toluene and the ozonolysis of alpha-pinene, J. Geophys. Res., 115, D24204, doi:10.1029/2010jd014387, 2010.

Nguyen, T. B., Laskin, A., Laskin, J., and Nizkorodov, S. A.: Brown carbon formation from ketoaldehydes of biogenic monoterpenes, Faraday Discuss., 165, 291-315, doi:10.1039/C3FD00036B, 2013.

Nojima, K., Kawaguchi, A., Ohya, T., Kanno, S., and Hirobe, M.: Studies on Photochemical-Reaction of Air-Pollutants .10. Identification of Nitrophenols in Suspended Particulates, Chem. Pharm. Bull., 31, 1047-1051, doi:10.1248/cpb.31.1047, 1983.

Noziere, B. and Esteve, W.: Organic reactions increasing the absorption index of atmospheric sulfuric acid aerosols, Geophys. Res. Lett., 32, L03812, doi:10.1029/2004g1021942, 2005.

Noziere, B. and Esteve, W.: Light-absorbing aldol condensation products in acidic aerosols: Spectra, kinetics, and contribution to the absorption index, Atmos. Environ., 41, 1150-1163, doi:10.1016/j.atmosenv.2006.10.001, 2007.

Olson, M. R., Garcia, M. V., Robinson, M. A., Van Rooy, P., Dietenberger, M. A., Bergin, M., and Schauer, J. J.: Investigation of black and brown carbon multiple-wavelengthdependent light absorption from biomass and fossil fuel combustion source emissions, J. Geophys. Res., 120, 6682-6697, doi:10.1002/2014JD022970, 2015.

Park, R. J., Kim, M. J., Jeong, J. I., Youn, D., and Kim, S.: A contribution of brown carbon aerosol to the aerosol light absorption and its radiative forcing in East Asia, Atmos. Environ., 44, 14141421, doi:10.1016/j.atmosenv.2010.01.042, 2010.

Petzold, A. and Schonlinner, M.: Multi-angle absorption photometry - a new method for the measurement of aerosol light absorption and atmospheric black carbon, J. Aerosol Sci., 35, 421-441, doi:10.1016/j.jaerosci.2003.09.005, 2004.

Plewka, A., Gnauk, T., Bruggemann, E., and Herrmann, H.: Biogenic contributions to the chemical composition of airborne par- ticles in a coniferous forest in Germany, Atmos. Environ., 40, S103-S115, doi:10.1016/j.atmosenv.2005.09.090, 2006.

Rizzo, L. V., Correia, A. L., Artaxo, P., Procópio, A. S., and Andreae, M. O.: Spectral dependence of aerosol light absorption over the Amazon Basin, Atmos. Chem. Phys., 11, 8899-8912, doi:10.5194/acp-11-8899-2011, 2011.

Sandradewi, S., Prevot, A. S. H., Szidat, S., Perron, N., Alfarra, M. A. Lanz, V. A., Weingartner, E., and Baltensperger, U.: Using Aerosol Light Absorption Measurements for the Quantitative Determination of Wood Burning and Traffic Emission Contributions to Particulate Matter, Environ. Sci. Technol., 42, 33163323, doi:10.1021/es702253m, 2008.

Scheinhardt, S., Müller, K., Spindler, G., and Herrmann, H.: Complexation of trace metals in size-segregated aerosol particles at nine sites in Germany, Atmos. Environ., 74, 102-109, doi:10.1016/j.atmosenv.2013.03.023, 2013.

Simoneit, B. R. T.: Biomass burning - A review of organic tracers for smoke from incomplete combustion, Appl. Geochem., 17, 129-162, doi:10.1016/S0883-2927(01)00061-0, 2002.

Song, C., Gyawali, M., Zaveri, R. A., Shilling, J. E., and Arnott, W. P.: Light absorption by secondary organic aerosol from alphapinene: Effects of oxidants, seed aerosol acidity, and relative humidity, J. Geophys. Res., 118, 741-749, doi:10.1002/jgrd.50767, 2013.

Spindler, G., Brüggemann, E., Gnauk, T., Grüner, A., Müller, K., and Herrmann, H.: A four-year size-segregated characterization study of particles $\operatorname{PM}(10), \operatorname{PM}(2.5)$ and $\operatorname{PM}(1)$ depending on air mass origin at Melpitz, Atmos. Environ., 44, 164-173, doi:10.1016/j.atmosenv.2009.10.015, 2010.

Stein, A. F., Draxler, R. R, Rolph, G. D., Stunder, B. J. B., Cohen, M. D., and Ngan, F.: NOAA's HYSPLIT atmospheric transport and dispersion modeling system, B. Am. Meteor. Soc., 96, 20592077, doi:10.1175/BAMS-D-14-00110.1, 2015.

Teich, M., van Pinxteren, D., and Herrmann, H.: Determination of nitrophenolic compounds from atmospheric particles using hollow-fiber liquid-phase microextraction and capillary electrophoresis/mass spectrometry analysis, Electrophoresis, 35, 1353-1361, doi:10.1002/elps.201300448, 2014.

Tremp, J., Mattrel, P., Fingler, S., and Giger, W.: Phenols and Nitrophenols as Tropospheric Pollutants - Emissions from Automobile Exhausts and Phase-Transfer in the Atmosphere, Water Air Soil Poll., 68, 113-123, doi:10.1007/Bf00479396, 1993.

Ulevicius, V., Bycenkiene, S., Remeikis, V., Garbaras, A., Kecorius, S., Andriejauskiene, J., Jasineviciene, D., and Mocnik, G.: Characterization of pollution events in the East Baltic region affected by regional biomass fire emissions, Atmos. Res., 98, 190-200, 2010.

Updyke, K. M., Nguyen, T. B., and Nizkorodov, S. A.: Formation of brown carbon via reactions of ammonia with secondary organic aerosols from biogenic and anthropogenic precursors, Atmos. Environ., 63, 22-31, doi:10.1016/j.atmosenv.2012.09.012, 2012.

Utry, N., Ajtai, T., Filep, A., Pinter, M. D., Hoffer, A., Bozoki, Z., and Szabo, G.: Mass specific optical absorption coefficient of HULIS aerosol measured by a four-wavelength photoacoustic spectrometer at NIR, VIS and UV wavelengths, Atmos. Environ., 69, 321-324, doi:10.1016/j.atmosenv.2013.01.003, 2013.

van Pinxteren, D. and Herrmann, H.: Determination of functionalised carboxylic acids in atmospheric particles and cloud wa- 
ter using capillary electrophoresis/mass spectrometry, J. Chromatogr. A, 1171, 112-123, doi:10.1016/j.chroma.2007.09.021, 2007.

van Pinxteren, D., Brüggemann, E., Gnauk, T., Iinuma, Y., Müller, K., Nowak, A., Achtert, P., Wiedensohler, A., and Herrmann, H.: Size- and time-resolved chemical particle characterization during CAREBeijing-2006: Different pollution regimes and diurnal profiles, J. Geophys. Res., 114, D00G09, doi:10.1029/2008jd010890, 2009.

van Pinxteren, D., Teich, M., and Herrmann, H.: Hollow fibre liquid-phase microextraction of functionalised carboxylic acids from atmospheric particles combined with capillary electrophoresis/mass spectrometric analysis, J. Chromatogr. A, 1267, 178-188, doi:10.1016/j.chroma.2012.06.097, 2012.

van Pinxteren, D., Fomba, K. W., Spindler, G., Muller, K., Poulain, L., Iinuma, Y., Loschau, G., Hausmann, A., and Herrmann, H.: Regional air quality in Leipzig, Germany: detailed source apportionment of size-resolved aerosol particles and comparison with the year 2000, Faraday Discuss., 189, 291-315, doi:10.1039/C5FD00228A, 2016.

Vione, D., Maurino, V., Minero, C., and Pelizzetti, E.: Phenol photonitration, Ann. Chim., 92, 919-929, 2002.

Wang, L., Li, Z. Q., Tian, Q. J., Ma, Y., Zhang, F. X., Zhang, Y., Li, D. H., Li, K. T., and Li, L.: Estimate of aerosol absorbing components of black carbon, brown carbon, and dust from groundbased remote sensing data of sun-sky radiometers, J. Geophys. Res.-Atmos., 118, 6534-6543, 2013.
Weingartner, E., Saathoff, H., Schnaiter, M., Streit, N., Bitnar, B., and Baltensperger, U.: Absorption of light by soot particles: determination of the absorption coefficient by means of aethalometers, J. Aerosol Sci., 34, 1445-1463, doi:10.1016/S00218502(03)00359-8, 2003.

Yan, C. Q., Zheng, M., Sullivan, A. P., Bosch, C., Desyaterik, Y., Andersson, A., Li, X. Y., Guo, X. S., Zhou, T., Gustafsson, O., and Collett, J. L.: Chemical characteristics and lightabsorbing property of water-soluble organic carbon in Beijing: Biomass burning contributions, Atmos. Environ., 121, 4-12, doi:10.1016/j.atmosenv.2015.05.005, 2015.

Yu, G., Bayer, A. R., Galloway, M. M., Korshavn, K. J., Fry, C. G., and Keutsch, F. N.: Glyoxal in aqueous ammonium sulfate solutions: products, kinetics and hydration effects, Environ. Sci. Technol., 45, 6336-6342, doi:10.1021/es200989n, 2011.

Zhang, X. L., Lin, Y. H., Surratt, J. D., and Weber, R. J.: Sources, composition and absorption Angstrom exponent of light-absorbing organic components in aerosol extracts from the Los Angeles Basin, Environ. Sci. Technol., 47, 3685-3693, doi:10.1021/es305047b, 2013.

Zhang, Y. Y., Müller, L., Winterhalter, R., Moortgat, G. K., Hoffmann, T., and Pöschl, U.: Seasonal cycle and temperature dependence of pinene oxidation products, dicarboxylic acids and nitrophenols in fine and coarse air particulate matter, Atmos. Chem. Phys., 10, 7859-7873, doi:10.5194/acp-10-7859-2010, 2010.

Zhao, R., Lee, A. K. Y., Huang, L., Li, X., Yang, F., and Abbatt, J. P. D.: Photochemical processing of aqueous atmospheric brown carbon, Atmos. Chem. Phys., 15, 6087-6100, doi:10.5194/acp15-6087-2015, 2015. 